\title{
Cardiac differentiation of pluripotent stem cells and implications for modeling the heart in health and disease
}

\author{
Harsha D. Devalla, ${ }^{1{ }^{\dagger}}$ and Robert Passier ${ }^{1,2+}$
}

\begin{abstract}
Cellular models comprising cardiac cell types derived from human pluripotent stem cells are valuable for studying heart development and disease. We discuss transcriptional differences that define cellular identity in the heart, current methods for generating different cardiomyocyte subtypes, and implications for disease modeling, tissue engineering, and regenerative medicine.
\end{abstract}

\section{INTRODUCTION}

Cardiovascular disease is a global epidemic responsible for 17.3 million deaths each year (1). Research into elucidating embryonic development of the heart and the etiology of diseases affecting this complex organ is essential for devising new therapeutic strategies to combat cardiac disease. The heart is a muscular organ made up of a variety of cells including cardiomyocytes (CMs), endothelial cells, smooth muscle cells, fibroblasts, epicardial cells, and endocardial cells. CMs make up about one-third of all of the cells in the heart (2) and are the fundamental work unit responsible for conduction of electrical impulses and contraction of cardiac muscle. The nonmyocyte components of the heart contribute to CM differentiation and proliferation as well as function (2). For the scope of this Review, we focus on the cell subtypes that constitute the CM fraction of the heart.

Structurally, the mammalian heart is divided into four chambersthe right and left atria and the right and left ventricles-together with components of the conduction system that ensure contraction of cardiac muscle (Fig. 1). Rhythmic contraction and relaxation of the heart ensures proper supply of blood and nutrients throughout the body. Each cycle of cardiac muscle activity is initiated by a specialized group of CMs of the sinoatrial node, situated at the entrance of the right atrium. These cells set the pace and rhythm of the heartbeat and are therefore called pacemaker cells. An electrical impulse generated by the sinoatrial node cells spreads through the atria, causing them to contract. The electrical impulse then travels to the atrioventricular node, where it is delayed, allowing sufficient time for the atria to contract. Then, the electrical activity spreads to the Purkinje (also called His-Purkinje) network, which innervates the muscular ventricular walls, resulting in ventricular contraction and ejection of blood into the pulmonary and systemic circulation.

The electrical activity recorded as an action potential is markedly different between the sinoatrial node, the atria, the atrioventricular node, the ventricles, and the Purkinje network. Any disturbance to this precisely orchestrated conduction process in the heart may lead to fatal arrhythmias. In the past decade, research using animal models

\footnotetext{
'Department of Anatomy and Embryology, Leiden University Medical Center, 2333 ZC Leiden, Netherlands. ${ }^{2}$ Department of Applied Stem Cell Technologies, Technical Medical Center, University of Twente, 7500 AE Enschede, Netherlands.

*Present address: Department of Medical Biology and Cardiology, Academic Medical Center, 1105AZ Amsterdam, Netherlands.

tCorresponding author.Email: h.d.devalla@amc.nl (H.D.D.); robert.passier@utwente.nl (R.P.)
}

has provided insights into the genetics and physiology of the heart. These studies have been complemented by work with cellular models using human pluripotent stem cells (hPSCs) including human embryonic stem cells (hESCs) (3) and human induced pluripotent stem cells (hiPSCs) (4). These cellular models have provided opportunities to study cardiac differentiation and disease in vitro. As the field continues to progress toward recapitulating complex cardiac disorders and to engineering three-dimensional (3D) models of the heart in vitro, we review our current understanding of regional transcriptional differences in the heart and provide an overview of current protocols for generating different CM subtypes in vitro. Then, we discuss current limitations of cellular models and future prospects for tissue engineering and cardiac regeneration.

\section{TRANSCRIPTIONAL DIFFERENCES CONTRIBUTING TO REGIONAL IDENTITY IN THE HEART}

The heart is the first functional organ in the embryo and is morphologically complete by 8 weeks of gestation in humans (5). The concerted action of a myriad of signaling pathways and transcriptional networks guides the specification of cardiac cell lineages; other excellent reviews present a detailed discussion of this subject $(6,7)$. Briefly, two progenitor cell types termed the first heart field and the second heart field contribute to the developing heart $(6,7)$. It is now understood that these cardiac progenitor cells are segregated as early as gastrulation and are programmed to contribute to distinct lineages (8). The first heart field contributes mainly to the left ventricle and parts of the atria of the developing heart. The right ventricle and outflow tract are formed by the addition of cells from the anterior second heart field; the majority of the atrial tissue is derived from the posterior second heart field $(6,7)$. In this section, we briefly outline the gene expression differences that confer distinct molecular and functional profiles on atrial, ventricular, and conduction cells that are essential for their diverse physiological roles in the heart.

During the course of cardiac specification and differentiation, selective transcriptional activation or repression in distinct cardiac compartments maintains their identity (Fig. 1). In human fetal and adult hearts, orphan nuclear transcription factors, COUP-TFI and COUP-TFII, are expressed selectively in the atrial myocardium (9). In mice, Coup-tfII regulates atrial identity by directly repressing a number of ventricular genes (10). Also, $\operatorname{Sin}$, a gene involved in calcium cycling in cells, is preferentially expressed in the atrial myocardium. 


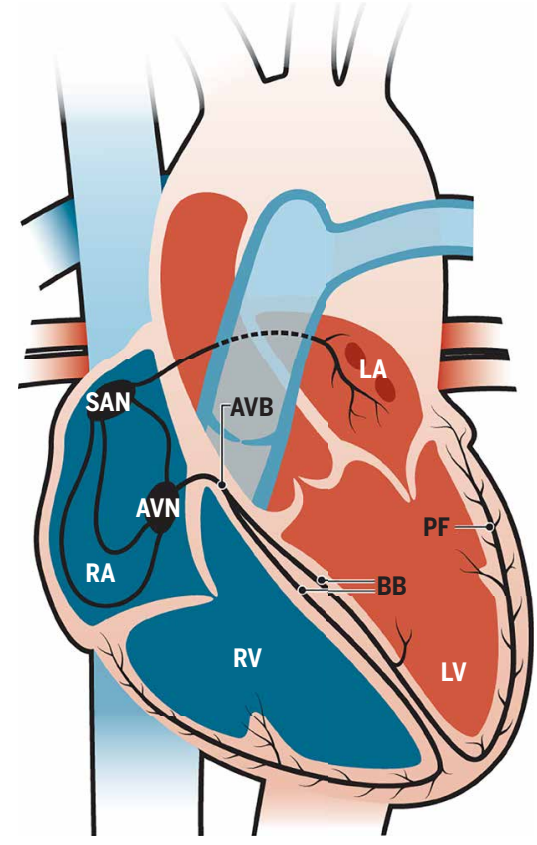

$\begin{array}{lll}\begin{array}{l}\text { Sinoatrial } \\ \text { node (SAN) }\end{array} & \begin{array}{l}\text { Right atrium } \\ \text { (RA) }\end{array} & \begin{array}{l}\text { Right ventricle } \\ \text { (RV) } \\ \text { ISL1 }\end{array} \\ \text { COUP-TFI } & \text { HAND2 } \\ \text { SHOX2 } & \text { COUP-TFII } & \text { HEY2 } \\ \text { IRX4 } & \text { SLN } & \\ \text { TBX18 } & \text { KCNA5 } & \\ \text { HCN4 } & \text { KCNJ3 } & \text { Left ventricle } \\ & \text { KCNJ5 } & \text { (LV) } \\ \text { Atrioventricular } & \text { Left atrium } & \text { HAND1 } \\ \text { node (AVN) } & \text { (LA) } & \text { HEY2 } \\ \text { TBX2 } & \text { PITX2 } & \text { IRX4 } \\ \text { TBX3 } & \text { COUP-TFI } & \\ \text { HCN4 } & \text { COUP-TFII } & \text { Purkinje fibers } \\ & \text { SLN } & \text { (PF) } \\ & \text { KCNA5 } & \text { PCP4 } \\ & \text { KCNJ3 } & \text { SCN10a } \\ & \text { KCNJ5 } & \end{array}$

Fig. 1. Gene expression during human heart development. Shown are the key genes expressed in various compartments of the human heart. The genes depicted are essential for regional identity and cardiac function, and their expression is dependent on the stage of cardiac development. This genetic blueprint for heart development is crucial for proper identification and characterization of human pluripotent stem cell (hPSC)-derived cardiomyocyte (CM) subtypes. AVB, atrioventricular bundle; $\mathrm{BB}$, bundle branches.

The expression of $\operatorname{Sin}$ mRNA increases progressively in the atria of mice during fetal development and persists in the adult atria $(11,12)$. Whereas these genes are expressed in both atrial chambers, expression of homeodomain transcription factor Pitx 2 is restricted to the left atrium where it suppresses the sinoatrial node transcriptional program to ensure that pacemaking activity is confined to the right atrium (13). Members of the hairy-related transcription factor family, Hey1 and Hey2, are also expressed differentially in the cardiac chambers and regulate atrioventricular boundary formation in the heart (14). Hey1 is expressed in the developing atria and is downregulated at embryonic day (E) 15.5 in mice. Hey2, on the other hand, is expressed in fetal and adult ventricles (15). Another transcription factor that is exclusive to the ventricles, both in the fetal and adult stages, is the Iroquois homeobox gene Irx4, which controls the expression of chamber-specific myosin heavy chain genes (16). In addi- tion, the helix-loop-helix transcription factors Hand1 and Hand 2 are both expressed in the cardiac crescent (a crescent-shaped structure consisting of heart-forming cells that appears at the onset of cardiogenesis). These transcription factors become progressively restricted to left and right ventricles, respectively, as heart development progresses (17).

Similarly, the molecular signature of the conduction system myocardium distinguishes it from the chamber myocardium, and differences also exist within the components of the conduction system. Several transcription factors such as Shox2, Isl1, Tbx3, and Tbx18 have been shown to be essential for the development and function of the sinoatrial node (18). Whereas the T box transcription factor $T b \times 3$ is expressed throughout the conduction system, expression of Isl1, Shox2, and $T b \times 18$ is localized to the sinoatrial node. In addition, $T b \times 3$ expression persists in the mature conduction system. Isl 1 is expressed in second heart field progenitor cells, but as development proceeds, its expression is confined to the sinoatrial node and declines gradually in the postnatal heart. The homeodomain transcription factor Shox2 is expressed in the sinus venosus and the sinoatrial node region of the developing heart. Last, the transcription factor Tbx18 is expressed in mesenchymal precursor cells, which give rise to sinoatrial node myocardium; Tbx18 expression persists in the head region of the sinoatrial node. In the developing atrioventricular canal, $B m p 2$ is specifically expressed early on and is required for the activation of $T b \times 2$ and $T b x 3$ in this region (18). On the other hand, expression of $P c p 4$, a gene involved in the regulation of CaMKII activity, is restricted to the ventricular conduction system (19).

Along with transcription factors and structural markers, a number of ion channels are differentially expressed in CM subtypes accounting for their differences in electrical function (20). Hcn4, encoding an inward current $\left(I_{\mathrm{f}}\right)$ ion channel, is initially expressed in first heart field progenitor cells, but as development progresses, its expression becomes predominant in components of the conduction system, particularly the sinoatrial node and the atrioventricular node (21). HCN4 expression has also been reported in the fetal and adult sinoatrial node of the human heart $(22,23)$. In the atria, genes encoding potassium channels such as KCNA5, KCNJ3, and KCNJ5 are preferentially expressed. KCNA5 encodes the $\mathrm{K}_{\mathrm{v}} 1.5$ ion channel, whereas KCNJ3 and KCNJ5 encode the Kir3.1 and Kir3.4 ion channels, respectively. $\mathrm{K}_{\mathrm{v}} 1.5$ ion channels conduct the ultrarapid delayed rectifier potassium current $I_{\text {Kur }}$. Kir3.1/3.4 ion channels form heteromeric complexes that conduct the acetylcholine-activated current $I_{\mathrm{K}, \mathrm{ACh}}(24,25)$; potassium currents $I_{\mathrm{K} 1}$, $I_{\mathrm{Kr}}$, and $I_{\mathrm{Ks}}$ predominantly, although not exclusively, occur in the ventricles (26). The inward-rectifier potassium current $I_{\mathrm{K} 1}$ is conducted by Kir2.1 channels encoded by the KCNJ2 gene, whereas alpha subunits of the delayed rectifier potassium currents $I_{\mathrm{Kr}}$ and $I_{\mathrm{Ks}}$ are mediated by $\mathrm{K}_{\mathrm{v}} 11.1$ channels encoded by the $K C N H 2$ gene and $\mathrm{K}_{\mathrm{v}} 7.1$ channels encoded by the KCNQ1 gene (Fig. 1) (26). Transmural (subendocardial, midmyocardial, and subepicardial) heterogeneity in ventricular action potentials has been observed and attributed to differential expression of various ion channels within the ventricular myocardium (27). Last, in Purkinje cells, the gene Scn10a encoding the $\mathrm{Na}_{\mathrm{v}} 1.8$ channel is highly expressed (28).

\section{DIFFERENTIATION OF PLURIPOTENT STEM CELLS INTO CM SUBTYPES}

Reproducing the molecular and functional profiles of specialized CM subtypes in vitro is needed (i) to increase our understanding of 
Table 1. Functional properties and diseases associated with different $\mathrm{CM}$ subtypes.

Cardiac subtype

Sinoatrial nodal cells

Atrioventricular nodal cells

Atrial cells

Ventricular cells

Purkinje cells

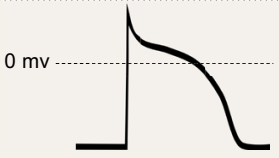

Action potential shape
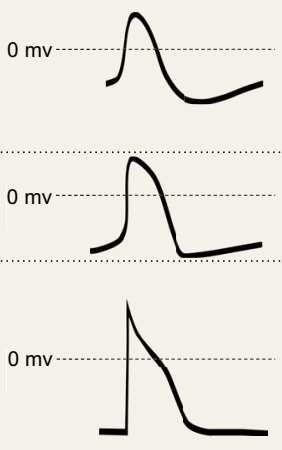

Properties

Spontaneous depolarization; slow action potential upstroke mediated by calcium currents and almost complete absence of fast sodium currents; lacks $I_{\mathrm{K} 1}$ current but has prominent $l_{\mathrm{f}}$ current

Similar to the sinoatrial nodal cells but with slower intrinsic rate

More negative resting membrane potential compared to pacemaker cells; shorter action potential duration compared to ventricular CMs; prominent $I_{\text {Kur }}$ and $I_{\text {KACh }}$ currents

Action potentials with a clear plateau phase; prominent $I_{\mathrm{K} 1}, I_{\mathrm{Kr}}$, and $I_{\mathrm{Ks}}$ currents; transmural heterogeneity

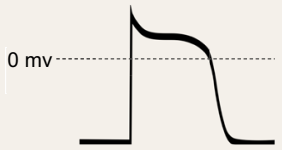

Longer action potentials with a more negative plateau phase; prominent $I_{\text {to }}$ current compared to ventricular CMs
Associated diseases

Sinus bradycardia, sinoatrial block, bradycardia-tachycardia syndrome

Atrioventricular block, atrioventricular nodal reentrant tachycardia

Atrial fibrillation

Rhythm disorders (long QT syndrome, LEOPARD syndrome, catecholaminergic polymorphic ventricular tachycardia), cardiomyopathies (hypertrophic cardiomyopathy, dilated cardiomyopathy, arrhythmogenic right ventricular cardiomyopathy)

Congenital histiocytoid cardiomyopathy developmental programs involved in lineage specification and (ii) to establish models that faithfully recapitulate in vivo cell types with applications in cardiac toxicity drug testing cardiac toxicity and regenerative medicine.

Since the introduction of the first protocols to coax hPSCs to differentiate into CMs in vitro $(29,30)$, many advances have been made that enhance the efficiency of this process. Recent techniques have introduced more refined small molecule-based strategies to generate greater percentages of CMs from hPSCs (31-33). In addition, methods have been introduced to enable purification of hPSC-derived CMs from other cell types. The use of a mitochondrial dye called TMRM (tetramethylrhodamine methyl ester) for enriching CMs in hESCderived cultures has been demonstrated (34). When stained with TMRM or other mitochondrial dyes, embryonic and neonatal rat CMs, CMs from whole rat hearts, and hESC-CMs showed a higher fluorescence intensity compared with non-CMs, allowing for successful separation (34). Furthermore, using a hESC reporter cell line expressing enhanced green fluorescent protein (eGFP) under the control of a key CM gene, NKX2.5 (NKX2.5-eGFP), a combination of cell surface markers (VCAM1 and SIRPA) were identified; these markers are now widely used for efficient purification of hPSC-derived CMs from other cell types $(35,36)$. Other genetically modified reporter cell lines targeting promoters of cardiac genes have also been described for separation of CMs in vitro; applications of these reporter cell lines are discussed in detail elsewhere (37). In a different approach, intrinsic differences in glucose and lactate metabolism between CMs and non-CMs have been exploited to aid in nongenetic purification of CMs (38). This method does not require fluorescence-activated cell sorting (FACS) for separation of CMs, thus facilitating the preparation of clinical-grade cells for therapeutic applications. Similar to the method using cell surface markers, metabolic-based CM purification techniques can be applied to different hPSC lines. Despite these advances for efficient generation and purification of CMs, most of the current protocols result in a heterogeneous mix of various cardiac subtypes, with ventricular-like CMs being the predominant cell type. Recent efforts have therefore focused on devising methods to generate different CM subtypes from hPSCs (Table 2).

We and others have shown that retinoic acid drives differentiation of PSCs into atrial-like CMs $(9,39)$. We have extensively characterized the resulting atrial-like CMs and have reported that they respond to atrial-specific ion channel blockers. Thus, these cells are a valuable tool for preclinical testing of drugs for treating atrial fibrillation (9). In another study, the bone morphogen protein (BMP) receptor antagonist Gremlin2 also enhanced differentiation of mouse ESCs (mESCs) into an atrial-like phenotype (40). Directed differentiation protocols have also been developed for generation of ventricular-like CMs from hPSCs. Inhibition of retinoic acid signaling (39) or canonical Wnt signaling (41) during differentiation of hPSCs into CMs has been shown to result in a relatively homogeneous population of ventricularlike CMs.

For the generation of pacemaker-like cells, several approaches including overexpression of key transcription factors, such as Tbx3 or Shox2, have yielded promising results $(42,43)$. Differentiation of mESCs overexpressing human TBX3 resulted in a higher percentage of pacemaker-like embryoid bodies (EBs) upon differentiation (42). Seeding of these induced pacemaker-like EBs on ventricular 
Table 2. Generating cardiac cell subtypes from PSCs. hESCs, human embryonic stem cells; mESCs, mouse embryonic stem cells; hiPSCs, human induced pluripotent stem cells; FGF, fibroblast growth factor; BMP4, bone morphogen protein 4 ; TGF- $\beta$, transcription growth factor- $\beta$; WNT, wingless/integrated; cAMP, cyclic adenosine 3',5'-monophosphate.

\begin{tabular}{|c|c|c|}
\hline Cardiac subtype & Source & Approach \\
\hline \multirow[b]{2}{*}{$\begin{array}{l}\text { Sinoatrial } \\
\text { node-like cells }\end{array}$} & mESCs & Overexpression of Tbx3, overexpression of Shox 2 \\
\hline & hESCs/hiPSCs & $\begin{array}{l}\text { Inhibition of FGF/BMP signaling in cardiac progenitor cells generated an NKX2.5 } / \text { Podoplanin }{ }^{+} \text {population } \\
\text { that gave rise to sinoatrial node-like cells upon differentiation }\end{array}$ \\
\hline \multirow{2}{*}{ Atrial-like cells } & $\mathrm{mESCs} / \mathrm{hESCs}$ & Activation of retinoic acid signaling \\
\hline & mESCs & Gremlin-based inhibition of BMP signaling \\
\hline Ventricular-like cells & hiPSCs & Inhibition of WNT signaling \\
\hline Purkinje cells & mESCs & Activation of cAMP signaling \\
\hline
\end{tabular}

slices of murine hearts ex vivo resulted in increased beating rates of the slices compared to those cocultured with control EBs. Alternatively, overexpression of human SHOX2 during differentiation of mESCs favored a sinoatrial node gene expression program (43). The resulting cells exhibited increased beating rates in vitro and were able to pace mouse hearts subjected to a complete heart block, where electrical impulses from the atria are blocked by the atrioventricular node and fail to reach the ventricles. In another approach, our group has shown that inducing MYC expression in differentiating hPSCs and subsequent addition of a cocktail of mitogens and small molecules maintained cells in a proliferative progenitor cell state (44). Furthermore, modulating fibroblast growth factor and BMP signaling in these cardiac progenitor cells resulted in distinct precursor cell populations, which could be further differentiated toward sinoatrial nodelike CMs or other CM subtypes. Although the above-mentioned studies exemplify potential strategies for the derivation of pacemaker cells in vitro, they involve genetic manipulation. Therefore, growth factorbased or small molecule-based approaches that can be applied over a wide range of cell lines would be superior; two such methods have been reported. The first method uses modulation of neuregulin/ErbB signaling during $\mathrm{hESC}$ differentiation to regulate the ratio of nodal versus chamber myocardial-like cells (45). Nodal-like cells in culture were identified using a chicken GATA6-GFP promoter-enhancer reporter construct, which labels the atrioventricular node and atrioventricular bundle in the adult heart (46). Therefore, nodal-like cells generated in this study may resemble the atrioventricular node or atrioventricular bundle; however, additional characterization is necessary to define their precise molecular and functional profiles. The second method involves a two-step protocol for efficient generation of sinoatrial node-like cells (47). Cardiac mesoderm was formed from hPSCs using a low concentration of Activin A and BMP4, and then was treated with a low concentration of BMP4 and a high concentration of retinoic acid to generate functional sinoatrial node-like cells (47). These sinoatrial node-like CM clusters were able to pace ventricularlike CM monolayer cultures in vitro. These clusters were also transplanted into rat hearts and then were analyzed ex vivo 2 weeks after induction of transient atrioventricular block. Ectopic electrical activity originating from the graft site was observed in the rat ventricles, reflecting the pacemaking potential of the sinoatrial node-like CMs generated in this study.
Last, cardiac Purkinje cells derived from in vitro differentiation of mESCs were efficiently purified using a contactin2:egfp reporter line (48). Furthermore, a small-molecule screen carried out on differentiating mESCs marked by CCS-lacZ (a reporter that labels the developing and mature cardiac conduction system) or contactin2:egfp demonstrated that sodium nitroprusside, used as a potent vasodilator, efficiently directed differentiation of mESCs toward a Purkinje cell phenotype and did so by activating cyclic AMP (adenosine $3^{\prime}, 5^{\prime}$ monophosphate) signaling (49).

\section{PATHOLOGIES AFFECTING SPECIFIC CM SUBTYPES}

A number of cardiac diseases originate in or are localized to specific cell types of the heart. Here, we briefly summarize some of these disorders and also discuss current developments regarding modeling these diseases with hPSCs in vitro.

Diseases of the sinoatrial node resulting in sinus node dysfunction are the major reason for implanting pacemakers in North America and Western Europe (1). Sinus node dysfunction is characterized by abnormal electrical impulse initiation or propagation by the sinoatrial node and involves conditions such as sinus bradycardia, sinus arrest, chronotropicincompetence, sinoatrial block, and bradycardia-tachycardia syndrome. The term "sick sinus syndrome" is commonly used to refer to the variety of symptoms associated with sinus node dysfunction. Aging remains a major risk factor for malfunction of the sinoatrial node owing to structural remodeling of atrial tissue accompanied by declining expression of the $\mathrm{Ca}_{\mathrm{v}} 1.2$ ion channel (50). However, sporadic cases of congenital sinus node dysfunction, caused by mutations in genes encoding ion channels such as SCN5A or HCN4, have also been reported (51). In vitro hPSC-based disease models of sinus node dysfunction have not been developed thus far because of lack of robust protocols for generating pacemaker-like cells. However, the protocols discussed above $(44,47)$ can now be used for the derivation of patient-specific sinoatrial node-like CMs.

Atrial fibrillation is marked by increased pace and quivering of the atrial chambers in an irregular pattern. It is the most common arrhythmia encountered by physicians in the clinic, and an estimated 13 million people suffer from this disease in the United States and Europe (1). Untreated atrial fibrillation can be life-threatening and predisposes patients to stroke, heart failure, or even sudden death. 
Risk for atrial fibrillation increases with age. However, mutations in ion channel genes, particularly myocardial potassium ion channel genes, such as KCNA5, KCNE2 and KCNQ1, or the sodium channel gene $S C N 5 A$, have been implicated in familial atrial fibrillation (52). In addition, genome-wide association studies have identified a number of single nucleotide polymorphisms associated with atrial fibrillation, particularly at the $4 \mathrm{q} 25$ locus that is in close proximity to the PITX2 gene (52). Given that protocols have now been devised for driving differentiation of hPSCs into atrial-like CMs $(9,39)$, modeling atrial fibrillation in vitro is now possible. In a recent study, the authors modeled atrial fibrillation by subjecting sheets of hESCderived atrial-like CMs to rapid external pacing in order to induce reentry, an aberrant electrophysiological mechanism responsible for perpetuation of atrial fibrillation (53). The next step will be to generate advanced cellular models of atrial fibrillation that use atrial CMs and non-CMs such as fibroblasts, a cell type that is widely implicated in pathophysiology of this disorder.

Pathological conditions affecting the atrioventricular node include atrioventricular conduction block or atrioventricular nodal reentrant tachycardia (1). The atrioventricular node is responsible for delaying the electrical impulse from the atria before it passes to the ventricles. It can also act as an accessory pacemaker in the event of sinoatrial node failure. Atrioventricular block results in obstruction of electrical impulse propagation from the atria to the ventricles. Atrioventricular nodal reentrant tachycardia, on the other hand, is the result of slow and fast electrophysiological pathways present in the atrioventricular node that lead to a reentry circuit. The electrical impulses thus self-perpetuate in the atrioventricular node, becoming the focal point of heart rate and rhythm and causing the atria and ventricles to contract rapidly. Modeling diseases of the atrioventricular node in vitro is complex due to lack of knowledge about how to direct differentiation toward an atrioventricular node-like cell phenotype. A model using multiple cell types such as sinoatrial node-like cells, atrial-like cells, and atrioventricular node-like cells would be useful for studying impulse propagation among these cell types and the mechanisms leading to atrioventricular block and reentry.

Numerous disorders affect the physiology and functioning of the cardiac ventricles. Ventricular tachyarrhythmias including ventricular fibrillation and ventricular tachycardia are the most frequently reported cardiac arrhythmias leading to sudden cardiac death. Multiple mechanisms, such as reentry, abnormal automaticity, or triggered activity in the ventricular myocardium, may underlie ventricular tachyarrhythmias. Cardiomyopathies, classified as dilated or hypertrophic, affect ventricular contraction and function. Systolic dysfunction and enlarged ventricular chambers characterize dilated cardiomyopathy. In hypertrophic cardiomyopathy, systolic and diastolic dysfunction is evident and is accompanied by thickening of the ventricular wall. Patients with dilated cardiomyopathy or hypertrophic cardiomyopathy are at increased risk for ventricular arrhythmias and heart failure.

Salient features of a few diseases where a phenotype is evident in ventricular-like CMs have been successfully recapitulated in vitro using hPSC-derived CMs. It has been particularly advantageous to study ion channel mutations using hPSC models due to the availability of an electrophysiological readout to assess the disease. CMs derived from hiPSCs have been generated to study various cardiac diseases affecting ventricular function including long QT syndrome (54-57), Brugada syndrome (55), catecholaminergic polymorphic ventricular tachycardia $(58,59)$, arrhythmogenic right ventricular cardiomyopathy (60), LEOPARD syndrome (61), dilated cardiomyopathy $(62)$, hypertrophic cardiomyopathy $(63,64)$, and hypoplastic left heart syndrome (65).

As for cardiac Purkinje cells, their involvement in triggering arrhythmias has been reported in various cases of genetic and acquired cardiac rhythm disorders. Moreover, a congenital cardiomyopathy syndrome termed histiocytoid cardiomyopathy, which is attributable to defects in Purkinje cell development (66), has been identified in human patients. The recent discovery of methods to isolate Purkinje cells from mESC-derived CM cultures $(48,49)$ offers a surrogate in vitro model for studying the role of this cell type in ventricular arrhythmias. However, additional research is necessary to test whether these protocols can be applied to hPSC lines to enable the use of Purkinje cells for disease modeling.

Although the ability of hiPSC-derived CMs to reproduce disease phenotypes in vitro has been demonstrated clearly, complex pathophysiological conditions involving multiple cardiac cell types have not yet been modeled. Knowledge of how to guide differentiation of hiPSCs into enriched populations of atrial-like, ventricular-like, or nodal-like cells and advances in tissue engineering will enable the modeling of cardiac disorders specific to certain subtypes.

\section{ASSEMBLING A HEART IN VITRO}

Although protocols are now emerging for directed differentiation of hPSCs into a variety of cardiac subtypes in vitro, there are a number of challenges that need to be overcome before the full potential of these cells for drug discovery/screening and regenerative medicine is realized.

\section{The importance of generating right/left $\mathrm{CM}$ subtypes}

Protocols addressing the derivation of right and left CM subtypes are needed to advance in vitro modeling of the heart. For example, one of the major sites of initiation of atrial fibrillation lies in the myocardium of the pulmonary sleeve of the left atrium. In a canine model of rapid atrial pacing, left atrial activation was reported to be more arrhythmogenic than right atrial activation (67). Although it has been demonstrated that the myocardial connection between the left atrium and pulmonary sleeve is a preferred site of atrial fibrillation onset (68), it is not clear whether intrinsic transcriptional and functional differences between right and left atrial CMs alter their susceptibility to arrhythmias. Genetic variants in close proximity to the left atrial gene PITX2 on the 4q25 locus have been linked to atrial fibrillation. PITX2 expression is reduced in patients with chronic atrial fibrillation (69), and mice heterozygous for Pitx2 have an increased susceptibility to arrhythmias (13). Similarly, the right and left ventricles also exhibit physiological differences and have distinct embryological origins. In the postnatal heart, right and left ventricles operate under different mechanical loads. Left ventricular dysfunction has been well studied in the context of myocardial ischemia or cardiomyopathies, but little is known about molecular and cellular mechanisms that contribute to right ventricular dysfunction. In mice, $\alpha_{1}$ adrenergic receptor stimulation evoked contrasting ionotropic responses from right and left ventricular trabeculae (70). Also, exposure to chronic high-altitude hypoxia resulted in differential gene expression changes in the right and left ventricles of humans (71). These studies point to innate differences between the left and right ventricular chambers that need to be investigated with relevant in vitro models. 


\section{Purification of CM subtypes}

Another shortcoming of current in vitro protocols is the lack of specific markers to distinguish cardiac subtypes in culture. This is especially important given that most directed differentiation protocols merely enrich for a certain CM subtype rather than yielding homogeneous cell populations. In combination with approaches for the isolation of hPSC-derived CMs discussed above, strategies to specifically select for atrial, ventricular, or nodal cells would be valuable. A few methods that are useful for enriching CM subtypes in culture are outlined below.

A hiPSC line expressing SLN-tdTomato was shown to be useful for purifying atrial-like CMs in culture. Cells with higher expression of tdTomato fluorescence resembled atrial CMs by molecular and functional analysis (72). SLN is expressed uniformly in both atrial chambers and would therefore be suitable for purification of right and left atrial-like cells. More recently, we demonstrated the value of a dual COUP-TFII-mCherry/NKX2-5-eGFP hESC reporter line for the identification and purification of atrial-like CMs (73). We and others (8) have previously shown that COUP-TFII is preferentially expressed in the atrial myocardium, and in conjunction with the CM marker NKX2.5, atrial and ventricular CMs can be efficiently separated in hPSC-derived CM cultures. Similarly, the use of a transgenic $M L C 2 \mathrm{~V}$-eGFP hESC line to enable purification of CMs from in vitro cultures has been reported (74). A 250-base pair promoter fragment of $M L C 2 V$ that is highly active in the cardiac ventricles was coupled to eGFP and stably expressed in hESCs by lentiviral transduction. CMs expressing eGFP could then be purified by FACS for downstream applications once the $M L C 2 V$ promoter became active during cardiac differentiation of hESCs. However, $M L C 2 \mathrm{~V}$ expression has been reported to be low in differentiated CMs and only increases with time in culture (32). Therefore, this approach may only be suitable for sorting CMs maintained under long-term culture conditions. Although the above strategies enable isolation of atrial or ventricular cells, they require the genetic modification of hPSC lines. Antibodies directed at cell surface antigens selective for each CM subtype would be ideal for isolation of specific cardiac cell types from different hPSC lines.

More recently, a label-free, noninvasive technique that identifies cardiac subtypes based on their intrinsic spectral differences identified by Raman spectroscopy has been reported (75). Although this is an innovative approach, it may not be ideal for accurate separation of hPSC-derived atrial or ventricular CMs. hPSC-derived CMs have an immature phenotype, which is reflected in their molecular signature. For example, the atrial myosin light chain isoform $M L C 2 A$ and the atrial natriuretic factor NPPA are expressed throughout the heart during early development and only become selectively expressed in the atria at later stages of development (76). Therefore, although the molecular signature and spectral signals of early differentiated hPSC-derived CMs may be indicative of an atrial-like identity, they may not display the same properties at later time points. Stage-specific analysis of the molecular composition of various CM subtypes and their spectral properties during differentiation will be necessary before Raman spectroscopy can be applied successfully to in vitro hPSCderived CM cultures. Furthermore, technical improvements are required be able to use Raman spectroscopy for routine high-throughput cell sorting procedures.

To enable purification of nodal cells, CD166 has been proposed as a marker for the isolation of presumptive pacemaker cells. CD166 is expressed on mESC-derived progenitor cells that progressed to become functional sinoatrial node-like cells (77). However, an earlier study reported the expression of CD166 in hESC-derived CMs (78); after FACS sorting, these cells gradually lost NKX2.5 expression and displayed increased rates of proliferation, suggesting that CD166 may be useful for sorting immature CMs. Therefore, additional studies are required to assess the possibility of using this marker for identifying pacemaker cells in hPSC-derived CM cultures. Alternatively, pacemaker cells could be sorted on the basis of surface expression of the ion channel HCN4. Notably, during embryonic development, HCN4-positive cells were identified as the first heart field progenitor cells (21). Therefore, this marker may only be suitable for isolating fully differentiated CMs at later stages of differentiation.

\section{Improving the maturity of hPSC-derived CMs}

One of the limitations hindering the use of hPSC-derived CMs for translational medicine is their immature phenotype. Structurally, hPSC-derived CMs lack T-tubules and have an underdeveloped apparatus for cycling calcium ions (79). At the electrophysiological level, they show a more depolarized resting membrane potential and a slower upstroke velocity (80). The force of contraction generated by hPSC-derived CMs is weaker than that of human fetal CMs from the second trimester (81). Moreover, as in embryonic CMs, hPSCderived CMs prefer glycolysis for energy production in contrast to adult CMs, which rely on oxidative phosphorylation with fatty acids as a predominant substrate $(82,83)$.

Several methods have been proposed to improve maturation of hPSC-derived CMs (Fig. 2). Treatment of hiPSC-derived CMs with tri-iodo-L-thyronine (T3) for 1 week in culture led to an increase in cell size and force of contraction (84). In vivo, myocardial cells receive a variety of paracrine signals from the endocardium and the epicardium. In particular, neuregulin 1 (NRG1), insulin-like growth factor 1 (IGF1), and Notch signaling have been shown to be crucial for the maturation of the ventricular chambers (85). In line with this, a recent study demonstrated a favorable effect on the maturity of hPSCderived CMs by coculturing them with endothelial cells (Fig. 2). The observed effect was attributed to the up-regulation of a set of microRNAs shown to target the ErbB4 receptor (86). Given that microRNAs act on thousands of target mRNAs, it is likely that the improved maturity of hPSC-derived CMs elicited by coculture with endothelial cells may have been mediated by more than one target gene. Moreover, NRG1 release from the endocardial endothelium and subsequent activation of ErbB2/4 receptors present on CMs are known to play a role in ventricular maturation (85). Another study identified up-regulation of the let-7 microRNA in long-term hESCderived CM cultures and also found that overexpression of the let-7 microRNA family enhanced structural, functional, and metabolic properties of hESC-derived CMs, possibly by acting upon target genes involved in the PI3K (phosphatidylinositol 3-kinase)/AKT/ insulin signaling cascade (87). Addition to the culture medium of insulin and dexamethasone in combination with 3-isobutyl-1-methylxanthine (60) or T3 (63) improved the metabolic characteristics of hPSC-derived CMs.

Alternatively, applying cycles of mechanical stress to PSC-derived CMs or cardiac progenitor cells in 3D culture enhanced expression of structural proteins associated with maturity and improved the force of contraction (Fig. 2) (88). Electrical stimulation of hiPSCderived CMs in 3D culture also improved ultrastructural and electrophysiological properties associated with CM maturation $(89,90)$. Although these studies suggest that $3 \mathrm{D}$ culture conditions have a 


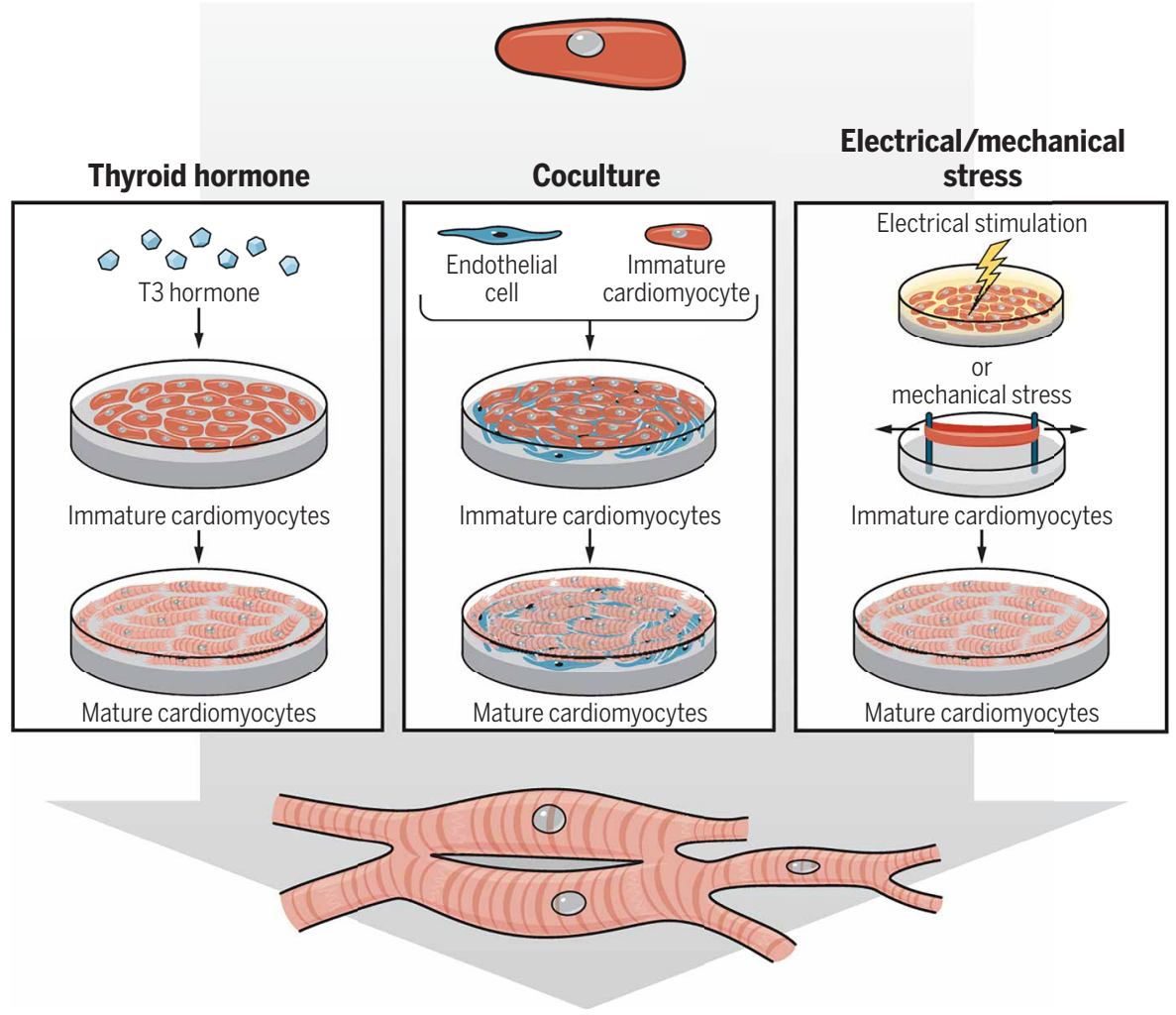

Fig. 2. Methods to generate mature hPSC-derived CMs in vitro. Structural, functional, and metabolic characteristics of hPSC-derived CMs resemble those of fetal human CMs but not of adult human CMs. hPSC-derived CMs can be driven toward a more mature adult CM phenotype by (left) the addition of tri-iodo-L-thyronine (T3) thyroid hormone to the culture medium, (middle) by coculture with nonmyocyte cell types such as endothelial cells, or (right) by applying electrical stimulation or cycles of mechanical stress to the hPSC-derived CMs in culture.

beneficial effect on CM maturation, additional physical and chemical cues to recreate the in vivo cardiac niche would promote overall maturity of hPSC-derived CMs.

\section{THE PROMISE OF TISSUE ENGINEERING}

Before we discuss the various tissue engineering approaches for building a heart in vitro, we need to consider the properties of nonCM cell types in the heart. Assembling various CM subtypes and non-CM cell types in vitro would provide the opportunity to mimic the microenvironment of the heart. Such an approach would be useful for many applications including drug efficacy/safety testing and modeling of patient-specific diseases, particularly those affecting the structure and morphology of the heart. As discussed, CMs constitute $30 \%$ of the cells in the mammalian heart, with the remainder comprising nonmyocyte cells. A study of adult mouse and human hearts showed that endothelial cells comprise about $50 \%$ of the heart, whereas fibroblasts comprise $<20 \%$ of the heart (91). Like CMs, cardiac endothelial cells are derived from the mesodermal germ layer; they are vital transporters of oxygen and nutrients as well as important modulators of vasomotor tone. In addition, paracrine action by endothelial cells through endothelin-1 underlies Purkinje cell differentiation in vivo (92). Epicardial cells are formed from a distinct tissue called the proepicardial organ during heart development and then migrate to envelop the entire surface of the heart. Notably, epicardial cells undergo an epithelial-tomesenchymal transition, forming fibroblasts and coronary vascular smooth muscle cells in the heart. In addition, activation of epicardium in response to cardiac insults and subsequent release of paracrine factors, such as retinoic acid, is crucial for mitigating myocardial damage and for promoting tissue repair (93). The epithelial-to-mesenchymal transition of epicardial cells contributes to the fibroblast lineage of the heart, although other sources such as endothelial cells, particularly under disease conditions, have been reported (94). Fibroblasts provide structural support to the heart through synthesis of extracellular matrix and also ensure propagation of electrical impulses by physically insulating the atria from the ventricles. The paracrine function of fibroblasts mediated by $\beta_{1}$ integrin signaling has been shown to promote CM proliferation in the embryonic mouse heart (95). Recently, protocols have been devised to generate endothelial cells, smooth muscle cells, and epicardial cells from hPSCs (96-100). In vitro studies to explore the interactions among hPSC-derived CMs and endothelial cells, smooth muscle cells, and epicardial cells derived from hPSCs should now gain momentum.

We will now discuss some of the current tissue engineering approaches for generating heart tissue in vitro. A variety of biomaterial scaffolds and substrates have been used to engineer heart tissue in vitro from different cell sources including hPSC-derived CMs (Fig. 3). The most widely studied constructs for seeding CMs use a hydrogel system comprising collagen and Matrigel $(101,102)$ or use fabricated scaffolds composed of biodegradable elastomers such as poly(glycerol sebacate) (103). The advantage of this system is the possibility for miniaturization and automation of heart tissue generation, which would be particularly useful for drug screening assays. Studies have also reported the design of vascularized engineered heart tissue constructs from hPSC-derived CMs (104-106). Moreover, recent reports suggest that hPSC-derived CMs in engineered heart tissue constructs display improved sarcomeric organization $(107,108)$ and functional properties (108). Chronic electrical stimulation of these engineered heart tissue constructs in vitro further improved their maturity and function (109).

Another strategy to create engineered heart tissue in vitro is to use decellularized whole hearts while leaving the vasculature intact (Fig. 3) (110-112). Proof of principle that this method could successfully produce engineered heart tissue was first demonstrated in decellularized rat hearts (110); more recently, it has also been successfully shown for human heart tissue. An acellular human heart scaffold was repopulated with hiPSC-derived CMs to create human heart tissue in vitro (111). In another study, multipotent $\mathrm{KDR}^{\text {low }} / \mathrm{c}-\mathrm{Kit}^{-}$cardiac progenitor cells derived from hiPSCs were injected into decellularized mouse hearts (112). These mouse hearts exhibited spontaneous contractions 20 days after perfusion with the cells, and an electrocardiogram could 


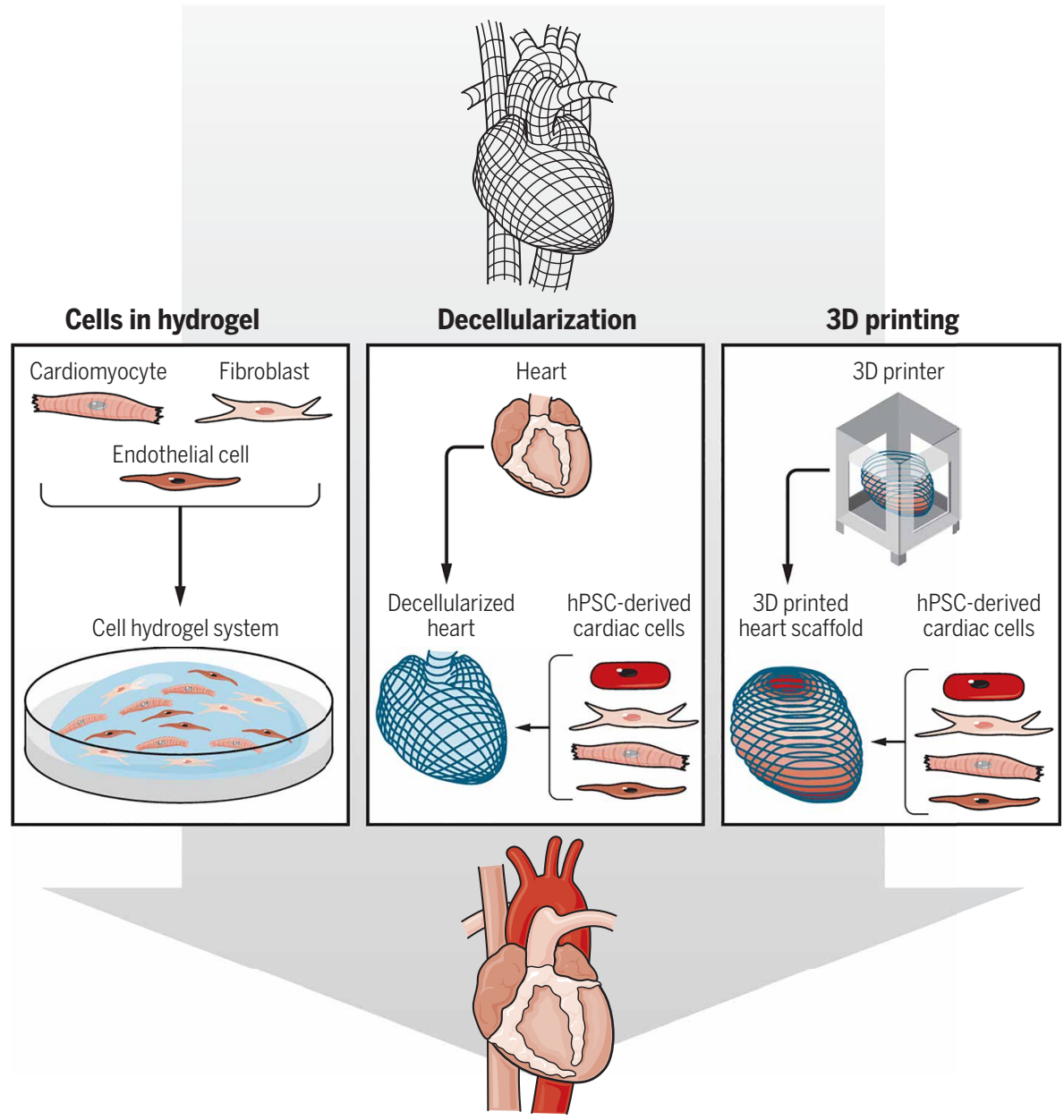

Fig. 3. Tissue engineering strategies to build a human heart in vitro. (Left) Engineered heart tissue can be generated by growing hPSC-derived CMs in a hydrogel system. (Middle) Engineered heart tissue has been generated from decellularized rat, pig, or human hearts that formed scaffolds, which were then repopulated by cardiac cells derived from hPSCs. (Right) In the future, hPSC-derived cardiac progenitor cells or cardiac cell subtypes will be bioprinted onto a three-dimensional (3D) heart scaffold to generate mini hearts in vitro. cell types similar to in vivo organs. Methods to generate organoids comprising various $\mathrm{CM}$ subtypes along with endothelial cells, smooth muscle cells, and fibroblasts would be useful for understanding interactions among cell types. Given that hPSCs cultured as EBs with appropriate growth factors generate a mixture of atrial, ventricular, and nodal cells, it seems feasible to generate heart organoids as $3 \mathrm{D}$ aggregates. However, a key step is the production of subtype-specific cardiac progenitor cells and their spatial organization in a 3D construct to obtain organoids with similar ratios of atrial, ventricular, and nodal cells as in native heart tissue.

Methods integrating biophysical techniques now make it possible to engineer 3D structures of living cells to facilitate construction of functional organs. One such technology that is revolutionizing the field of medicine is $3 \mathrm{D}$ printing. It has already been successfully used for the production of medical devices such as implants and prostheses (114). Recent advances have enabled the application of this technique for printing living tissue (termed $3 \mathrm{D}$ bioprinting). A new method using a thermoreversible support bath to enable hydrogelbased fabrication of complex anatomical structures has been used to print a 3D chicken heart (115). Alginate hydrogel has been used for 3D bioprinting of hiPSCs and their subsequent differentiation into hepatocyte-like cells to produce miniature livers in vitro (116). In the future, hPSC-derived CMs could be layered to reproduce the 3D architecture of the heart, and microfluidics could be used to simulate blood flow in the tissue. Exciting improvements are already underway in 3D bioprinting technologies that will facilitate fabrication of be recorded, albeit with an irregular wave pattern indicating a lack of synchronous conduction. This study noted an effect of extracellular matrix on CM commitment. The CMs populating the atria expressed more $M L C 2 A$ and SLN and less IRX4 compared to CMs populating the ventricles (112). Implanting appropriate CM subtypes into a heart framework with preserved chamber geometry is an interesting approach, but infusing the decellularized heart matrix with hPSC-derived atrial or ventricular CMs at the desired location and maintaining their viability are likely to be challenging. Also, this method would be less suitable for application in automated preclinical screening assays. Nonetheless, this approach may be of value for modeling the pressure-volume relationship of the heart, studying multicellular phenotypes in cardiac diseases and investigating overall physiological function and cell maturation in an in vitro setting. Generating 3D organoids from hPSCs is now an exciting area of research, and protocols for derivation of cerebral, gastric, intestinal, kidney, and liver organoids have been reported (113). Generation of organoids from hPSCs requires a stage-specific differentiation protocol recapitulating endogenous development. The resulting $3 \mathrm{D}$ tissue has been reported to contain self-organizing clusters of multiple human-scale constructs with a mosaic of desired cell types achieved through multidispensing modules and integrated microchannels for delivery of nutrients to the cells (117).

To take this technology to the next level, it is crucial to devise methods to generate mature CM and non-CM cell types in combination with specific selection procedures. This will enable construction of robust heart models where addition of different cell types can be precisely controlled. Fabricating advanced 3D multicellular mini organs will be valuable for studying cardiac physiology. Integrating bioengineering technologies with microfabrication, microfluidics, electronics, and nanotechnology to build miniature human tissues, so-called organ-on-a-chip models, will accelerate our understanding of human disease and our ability to rapidly screen potential new drugs (118).

\section{TOWARD REGENERATIVE MEDICINE}

The potential to generate hPSC-based tissues with a morphology and architecture that resemble the native organ will also have a major impact on regenerative medicine. In the past decade, there has been 
remarkable interest in the potential use of hPSC-derived CMs for cardiac repair. The most valuable $\mathrm{CM}$ subtype for applications in regenerative medicine is a ventricular-like cell, given that congestive heart failure caused by, for example, diabetes, pulmonary hypertension, or coronary artery disease frequently leads to ventricular dysfunction. A number of studies have tested the potential of hPSC-derived CMs for heart repair. Transplantation of hPSC-derived CMs into damaged hearts of small animal models has demonstrated that the transplanted cells engraft in the host myocardium and may improve function, at least temporarily (119-121). Human engineered heart tissue constructs transplanted into infarcted rodent myocardium in vivo showed engraftment and long-term survival but did not lead to any notable functional improvement (122). A study performed in monkeys with induced ischemia-reperfusion injury examined the effects of injecting 1 billion hESC-derived CMs into the infarcted myocardium; the investigators found that the hESC-derived CMs induced remuscularization of large areas of damaged tissue (123). Despite this encouraging finding, this study also reported the occurrence of arrhythmias after injection of hESC-derived CMs into the monkey heart, although these were not life threatening. These findings reiterate the need for improved protocols to enable application of hPSC-derived CMs for regenerative therapies.

In other recent developments, the prospect of using hPSC-derived cardiac progenitor cells for cardiac repair has been tested. One study demonstrated a favorable effect of transplanting hESC-derived cardiac progenitor cells (124) into a patient with severe heart failure (125). Cardiac progenitor cells expressing SSEA1 and ISL1 (124) were embedded in a fibrin scaffold and delivered surgically to the infarcted area of the patient. An improvement in left ventricular ejection fraction was noted at 3 months after transplantation, and the beneficial effect was sustained for 6 months after transplantation. The patient showed no arrhythmias, tumor formation, or immune rejection. Despite this encouraging finding, randomized controlled clinical trials with long-term follow-up need to be conducted, and mechanisms leading to improved function need to be elucidated before any conclusions can be drawn about the effectiveness of this therapy. In a similar approach, multipotent hESC-derived cardiac progenitor cells coexpressing kinase insert domain receptor (KDR) and plateletderived growth factor receptor $\alpha(\operatorname{PDGFR} \alpha)$ were transplanted into infarcted rodent myocardium (126). Subsequent analysis of the graft suggested that human cardiac progenitor cells expressing KDR and PDGFR $\alpha$ differentiated primarily into CMs in vivo; an improvement in systolic function was observed comparable to that of infarcted rat hearts transplanted with hESC-derived CMs. Although the differentiation potential of KDR-positive mesodermal cardiac progenitor cells to $\mathrm{CM}$ and endothelial cell lineages has been demonstrated (127), transplantation of these cardiac progenitor cells into infarcted rat heart did not result in improved vascularization of the graft compared to hESC-derived CMs. Moving forward, the success of cell transplantation approaches to rescue heart failure will depend on the identification of the right cell type (cardiac progenitor cells versus $\mathrm{CMs}$ ) to improve ventricular function. Also, care should be taken to avoid heterogeneity in the cell preparations (for example, nodal-like cells) to prevent arrhythmias.

Apart from heart failure, hPSC-derived CM subtypes would also be valuable for the treatment of congenital heart disease. Congenital heart disease has been documented in six to eight cases per 1000 live births each year with septal defects (atrial, ventricular, or atrioventricular) being the most commonly encountered (1). Pediatric surgery, and often multiple surgeries, may be required to correct complex structural abnormalities. Currently used xenografts or homografts obtained from human cadavers are not optimal (128); thus, engineered grafts composed of hPSC-derived CM subtypes may be a promising alternative. The challenge, however, is to identify the right combination of cell types (for example, CMs, endocardial cells, etc.) to populate the grafts, which should also have the capacity to integrate and remodel with the growing heart of the recipient.

Finally, hPSC-derived sinoatrial node-like CMs would be immensely valuable as a biological pacemaker for the treatment of sinus node dysfunction. With the recent introduction of a growth factor protocol for the generation of sinoatrial node-like CMs (47), it would be interesting to test the functionality of these cells in large animal models of sinus node dysfunction. It is important to realize that the site of transplantation in the host myocardium (atrial versus ventricular) and autonomic innervation in the region may greatly influence homing of the sinoatrial node-like CMs and ultimately will determine the pacemaker function of these cells in vivo.

Many hurdles need to be overcome before clinical trials can be initiated to evaluate the use of hPSC-derived CMs for regenerative medicine. Foremost, efficient production and purification of appropriate cardiac cell types with improved maturity and compliant with good manufacturing practices are essential prerequisites for realizing the potential of hPSC-derived CMs for heart repair.

\section{CONCLUSIONS}

Recent advances in stem cell biology have enhanced our understanding of cardiac differentiation and disease. Now, it is time to increase our efforts in the translation of this information for preclinical and potential clinical applications. To achieve this, we must improve culture conditions and protocols for generating hPSC-derived CM subtypes that have comparable structural and functional properties to native adult human CMs. This, together with state-of-the-art bioprinting and nanotechnologies, will enable the development of organ-on-achip models that mimic the physiology and organization of the human heart in vitro. Such multidisciplinary approaches that integrate biology with technology to build a human heart in a dish will pave the way for advanced disease modeling and drug screening, ultimately contributing to progress in regenerative and personalized medicine.

\section{REFERENCES AND NOTES}

1. D. Mozaffarian, E. J. Benjamin, A. S. Go, D. K. Arnett, M. J. Blaha, M. Cushman, S. de Ferranti, J.-P. Després, H. J. Fullerton, V. J. Howard, M. D. Huffman, S. E. Judd, B. M. Kissela, D. T. Lackland, J. H. Lichtman, L. D. Lisabeth, S. Liu, R. H. Mackey, D. B. Matchar, D. K. McGuire, E. R. Mohler, C. S. Moy, P. Muntner, M. E. Mussolino, K. Nasir, R. W. Neumar, G. Nichol, L. Palaniappan, D. K. Pandey, M. J. Reeves, C. J. Rodriguez, P. D. Sorlie, J. Stein, A. Towfighi, T. N. Turan, S. S. Virani, J. Z. Willey, D. Woo, R. W. Yeh, M. B. Turner; American Heart Association Statistics Committee and Stroke Statistics Subcommittee, Heart disease and stroke statistics - 2015 update: A report from the American Heart Association. Circulation 131, e29-e322 (2015).

2. D. Tirziu, F. J. Giordano, M. Simons, Cell communications in the heart. Circulation 122 928-937 (2010).

3. J. A. Thomson, J. Itskovitz-Eldor, S. S. Shapiro, M. A. Waknitz, J. J. Swiergiel, V. S. Marshall, J. M. Jones, Embryonic stem cell lines derived from human blastocysts. Science 282, 1145-1147 (1998).

4. K. Takahashi, M. Tanabe, M. Ohnuki, M. Narita, T. Ichisaka, S. Tomoda, S. Yamanaka, Induction of pluripotent stem cells from adult human fibroblasts by defined factors. Cell 131, 861-872 (2007).

5. A. Włoch, W. Rozmus-Warcholinska, B. Czuba, D. Borowski, S. Włoch, W. Cnota, K. Sodowski, K. Szaflik, J. C. Huhta, Doppler study of the embryonic heart in normal pregnant women. J. Matern. Fetal. Neonatal. Med. 20, 533-539 (2007). 
6. S. M. Meilhac, F. Lescroart, C. Blanpain, M. E. Buckingham, Cardiac cell lineages that form the heart. Cold Spring Harb. Perspect. Med. 4, ao13888 (2014).

7. S. L. Paige, K. Plonowska, A. Xu, S. M. Wu, Molecular regulation of cardiomyocyte differentiation. Circ. Res. 116, 341-353 (2015).

8. W. P. Devine, J. D. Wythe, M. George, K. Koshiba-Takeuchi, B. G. Bruneau, Early patterning and specification of cardiac progenitors in gastrulating mesoderm. eLife, 03848 (2014).

9. H. D. Devalla, V. Schwach, J. W. Ford, J. T. Milnes, S. El-Haou, C. Jackson, K. Gkatzis, D. A. Elliott, S. M. Chuva de Sousa Lopes, C. L. Mummery, A. O. Verkerk, R. Passier, Atrial-like cardiomyocytes from human pluripotent stem cells are a robust preclinical model for assessing atrial-selective pharmacology. EMBO Mol. Med. 7, 394-410 (2015).

10. S.-P. Wu, C.-M. Cheng, R. B. Lanz, T. Wang, J. L. Respress, S. Ather, W. Chen, S.-J. Tsai, X. H. Wehrens, M.-J. Tsai, Atrial identity is determined by a COUP-TFIl regulatory network. Dev. Cell 25, 417-426 (2013).

11. S. Minamisawa, Y. Wang, J. Chen, Y. Ishikawa, K. R. Chien, R. Matsuoka, Atrial chamberspecific expression of sarcolipin is regulated during development and hypertrophic remodeling. J. Biol. Chem. 278, 9570-9575 (2003).

12. P. Vangheluwe, M. Schuermans, E. Zádor, E. Waelkens, L. Raeymaekers, F. Wuytack, Sarcolipin and phospholamban mRNA and protein expression in cardiac and skeletal muscle of different species. Biochem. J. 389, 151-159 (2005).

13. J. Wang, E. Klysik, S. Sood, R. L. Johnson, X. H. T. Wehrens, J. F. Martin, Pitx2 prevents susceptibility to atrial arrhythmias by inhibiting left-sided pacemaker specification. Proc. Natl. Acad. Sci. U.S.A. 107, 9753-9758 (2010)

14. H. Kokubo, S. Tomita-Miyagawa, Y. Hamada, Y. Saga, Hesr1 and Hesr2 regulate atrioventricular boundary formation in the developing heart through the repression of Tbx2. Development 134, 747-755 (2007).

15. O. Nakagawa, M. Nakagawa, J. A. Richardson, E. N. Olson, D. Srivastava, HRT1, HRT2, and HRT3: A new subclass of bHLH transcription factors marking specific cardiac, somitic, and pharyngeal arch segments. Dev. Biol. 216, 72-84 (1999).

16. Z.-Z. Bao, B. G. Bruneau, J. G. Seidman, C. E. Seidman, C. L. Cepko, Regulation of chamber-specific gene expression in the developing heart by Irx4. Science $\mathbf{2 8 3}$, 1161-1164 (1999).

17. D. Srivastava, HAND proteins: Molecular mediators of cardiac development and congenital heart disease. Trends Cardiovasc. Med. 9, 11-18 (1999).

18. J. H. van Weerd, V. M. Christoffels, The formation and function of the cardiac conduction system. Development 143, 197-210 (2016).

19. E. E. Kim, A. Shekhar, J. Lu, X. Lin, F.-Y. Liu, J. Zhang, M. Delmar, G. I. Fishman, PCP4 regulates Purkinje cell excitability and cardiac rhythmicity. J. Clin. Invest. 124, 5027-5036 (2014).

20. G. Schram, M. Pourrier, P. Melnyk, S. Nattel, Differential distribution of cardiac ion channel expression as a basis for regional specialization in electrical function. Circ. Res. 90, 939-950 (2002).

21. D. Später, M. K. Abramczuk, K. Buac, L. Zangi, M. W. Stachel, J. Clarke, M. Sahara, A. Ludwig, K. R. Chien, A HCN4+ cardiomyogenic progenitor derived from the first heart field and human pluripotent stem cells. Nat. Cell Biol. 15, 1098-1106 (2013).

22. N. J. Chandler, I. D. Greener, J. O. Tellez, S. Inada, H. Musa, P. Molenaar, D. DiFrancesco, M. Baruscotti, R. Longhi, R. H. Anderson, R. Billeter, V. Sharma, D. C. Sigg, M. R. Boyett, $\mathrm{H}$. Dobrzynski, Molecular architecture of the human sinus node: Insights into the function of the cardiac pacemaker. Circulation 119, 1562-1575 (2009).

23. A. Sizarov, H. D. Devalla, R. H. Anderson, R. Passier, V. M. Christoffels, A. F. M. Moorman, Molecular analysis of patterning of conduction tissues in the developing human heart. Circ. Arrhythm. Electrophysiol. 4, 532-542 (2011).

24. Z. Wang, B. Fermini, S. Nattel, Sustained depolarization-induced outward current in human atrial myocytes. Evidences for a novel delayed rectifier $\mathrm{K}+$ current similar to $\mathrm{K}_{\mathrm{v}} 1.5$ cloned channel currents. Circ. Res. 73, 1061-1076 (1993).

25. G. Krapivinsky, E. A. Gordon, K. Wickman, B. Velimirović, L. Krapivinsky, D. E. Clapham, The G-protein-gated atrial $\mathrm{K}^{+}$channel $\mathrm{I}_{\mathrm{KACh}}$ is a heteromultimer of two inwardly rectifying $\mathrm{K}^{+}$-channel proteins. Nature 374, 135-141 (1995).

26. U. Ravens, E. Cerbai, Role of potassium currents in cardiac arrhythmias. Europace 10, 1133-1137 (2008).

27. B. J. D. Boukens, V. M. Christoffels, R. Coronel, A. F. M. Moorman, Developmental basis for electrophysiological heterogeneity in the ventricular and outflow tract myocardium as a substrate for life-threatening ventricular arrhythmias. Circ. Res. 104, 19-31 (2009).

28. N. Sotoodehnia, A. Isaacs, P. I. W. de Bakker, M. Dörr, C. Newton-Cheh, I. M. Nolte, P. van der Harst, M. Müller, M. Eijgelsheim, A. Alonso, A. A. Hicks, S. Padmanabhan, C. Hayward, A. V. Smith, O. Polasek, S. Giovannone, J. Fu, J. W. Magnani, K. D. Marciante, A. Pfeufer, S. A. Gharib, A. Teumer, M. Li, J. C. Bis, F. Rivadeneira, T. Aspelund, A. Köttgen, T. Johnson, K. Rice, M. P. Sie, Y. A. Wang, N. Klopp, C. Fuchsberger, S. H. Wild, I. Mateo Leach, K. Estrada, U. Völker, A. F. Wright, F. W. Asselbergs, J. Qu, A. Chakravarti, M. F. Sinner, J. A. Kors, A. Petersmann, T. B. Harris, E. Z. Soliman, P. B. Munroe, B. M. Psaty, B. A. Oostra, L. A. Cupples, S. Perz, R. A. de Boer, A. G. Uitterlinden, H. Völzke, T. D. Spector, F. Y. Liu, E. Boerwinkle, A. F. Dominiczak, J. I. Rotter, G. van Herpen, D. Levy, H. E. Wichmann, W. H. van Gilst, J. C. Witteman, H. K. Kroemer, W. H. Kao, S. R. Heckbert,
T. Meitinger, A. Hofman, H. Campbell, A. R. Folsom, D. J. van Veldhuisen,

C. Schwienbacher, C. J. O'Donnell, C. B. Volpato, M. J. Caulfield, J. M. Connell, L. Launer,

X. Lu, L. Franke, R. S. Fehrmann, G. te Meerman, H. J. Groen, R. K. Weersma,

L. H. van den Berg, C. Wijmenga, R. A. Ophoff, G. Navis, I. Rudan, H. Snieder, J. F. Wilson,

P. P. Pramstaller, D. S. Siscovick, T. J. Wang, V. Gudnason, C. M. van Duijn, S. B. Felix,

G. I. Fishman, Y. Jamshidi, B. H. Stricker, N. J. Samani, S. Kääb, D. E. Arking, Common

variants in 22 loci are associated with QRS duration and cardiac ventricular conduction.

Nat. Genet. 42, 1068-1076 (2010).

29. I. Kehat, D. Kenyagin-Karsenti, M. Snir, H. Segev, M. Amit, A. Gepstein, E. Livne, O. Binah, J. Itskovitz-Eldor, L. Gepstein, Human embryonic stem cells can differentiate into myocytes with structural and functional properties of cardiomyocytes. J. Clin. Invest. 108, 407-414 (2001).

30. C. Mummery, D. Ward, C. E. van den Brink, S. D. Bird, P. A. Doevendans, T. Opthof, A. Brutel de la Riviere, L. Tertoolen, M. van der Heyden, M. Pera, Cardiomyocyte differentiation of mouse and human embryonic stem cells. J. Anat. 200, 233-242 (2002).

31. P. W. Burridge, E. Matsa, P. Shukla, Z. C. Lin, J. M. Churko, A. D. Ebert, F. Lan, S. Diecke, B. Huber, N. M. Mordwinkin, J. R. Plews, O. J. Abilez, B. Cui, J. D. Gold, J. C. Wu, Chemically defined generation of human cardiomyocytes. Nat. Methods 11, 855-860 (2014).

32. X. Lian, C. Hsiao, G. Wilson, K. Zhu, L. B. Hazeltine, S. M. Azarin, K. K. Raval, J. Zhang, T. J. Kamp, S. P. Palecek, Robust cardiomyocyte differentiation from human pluripotent stem cells via temporal modulation of canonical Wnt signaling. Proc. Natl. Acad. Sci. U.S.A. 109, E1848-E1857 (2012).

33. X. Lian, X. Bao, M. Zilberter, M. Westman, A. Fisahn, C. Hsiao, L. B. Hazeltine, K. K. Dunn, T. J. Kamp, S. P. Palecek, Chemically defined, albumin-free human cardiomyocyte generation. Nat. Methods 12, 595-596 (2015).

34. F. Hattori, H. Chen, H. Yamashita, S. Tohyama, Y.-s. Satoh, S. Yuasa, W. Li, H. Yamakawa, T. Tanaka, T. Onitsuka, K. Shimoji, Y. Ohno, T. Egashira, R. Kaneda, M. Murata, K. Hidaka, T. Morisaki, E. Sasaki, T. Suzuki, M. Sano, S. Makino, S. Oikawa, K. Fukuda, Nongenetic method for purifying stem cell-derived cardiomyocytes. Nat. Methods 7, 61-66 (2010).

35. D. A. Elliott, S. R. Braam, K. Koutsis, E. S. Ng, R. Jenny, E. L. Lagerqvist, C. Biben, T. Hatzistavrou, C. E. Hirst, Q. C. Yu, R. J. C. Skelton, D. Ward-van Oostward, S. M. Lim, O. Khammy, X. Li, S. M. Hawes, R. P. Davis, A. L. Goulburn, R. Passier, O. W. J. Prall, J. M. Haynes, C. W. Pouton, D. M. Kaye, C. L. Mummery, A. G. Elefanty, E. G. Stanley, $N K X 2-5^{\text {eGFP/w }} \mathrm{hESCS}$ for isolation of human cardiac progenitors and cardiomyocytes. Nat. Methods 8, 1037-1040 (2011).

36. N. C. Dubois, A. M. Craft, P. Sharma, D. A. Elliott, E. G. Stanley, A. G. Elefanty, A. Gramolini, G. Keller, SIRPA is a specific cell-surface marker for isolating cardiomyocytes derived from human pluripotent stem cells. Nat. Biotechnol. 29, 1011-1018 (2011).

37. S. C. den Hartogh, R. Passier, Fluorescent reporters in human pluripotent stem cells: Contributions to cardiac differentiation and their applications in cardiac disease and toxicity. Stem Cells 34, 13-26 (2016).

38. S. Tohyama, F. Hattori, M. Sano, T. Hishiki, Y. Nagahata, T. Matsuura, H. Hashimoto, T. Suzuki, H. Yamashita, Y. Satoh, T. Egashira, T. Seki, N. Muraoka, H. Yamakawa, Y. Ohgino, T. Tanaka, M. Yoichi, S. Yuasa, M. Murata, M. Suematsu, K. Fukuda, Distinct metabolic flow enables large-scale purification of mouse and human pluripotent stem cell-derived cardiomyocytes. Cell Stem Cell 12, 127-137 (2013).

39. Q. Zhang, J. Jiang, P. Han, Q. Yuan, J. Zhang, X. Zhang, Y. Xu, H. Cao, Q. Meng, L. Chen, T. Tian, X. Wang, P. Li, J. Hescheler, G. Ji, Y. Ma, Direct differentiation of atrial and ventricular myocytes from human embryonic stem cells by alternating retinoid signals. Cell Res. 21, 579-587 (2010).

40. V. Tanwar, J. B. Bylund, J. Hu, J. Yan, J. M. Walthall, A. Mukherjee, W. H. Heaton, W-D. Wang, F. Potet, M. Rai, S. Kupershmidt, E. W. Knapik, A. K. Hatzopoulos, Gremlin 2 promotes differentiation of embryonic stem cells to atrial fate by activation of the JNK signaling pathway. Stem Cells 32, 1774-1788 (2014).

41. I. Karakikes, G. D. Senyei, J. Hansen, C.-W. Kong, E. U. Azeloglu, F. Stillitano, D. K. Lieu, J. Wang, L. Ren, J.-S. Hulot, R. lyengar, R. A. Li, R. J. Hajjar, Small molecule-mediated directed differentiation of human embryonic stem cells toward ventricular cardiomyocytes. Stem Cells Transl. Med. 3, 18-31 (2014).

42. J. J. Jung, B. Husse, C. Rimmbach, S. Krebs, J. Stieber, G. Steinhoff, A. Dendorfer, W.-M. Franz, R. David, Programming and isolation of highly pure physiologically and pharmacologically functional sinus-nodal bodies from pluripotent stem cells. Stem Cell Reports 2, 592-605 (2014).

43. V. lonta, W. Liang, E. H. Kim, R. Rafie, A. Giacomello, E. Marbán, H. C. Cho, SHOX2 overexpression favors differentiation of embryonic stem cells into cardiac pacemaker cells, improving biological pacing ability. Stem Cell Reports 4, 129-142 (2015).

44. M. J. Birket, M. C. Ribeiro, A. O. Verkerk, D. Ward, A. R. Leitoguinho, S. C. den Hartogh, V. V. Orlova, H. D. Devalla, V. Schwach, M. Bellin, R. Passier, C. L. Mummery, Expansion and patterning of cardiovascular progenitors derived from human pluripotent stem cells. Nat. Biotechnol. 33, 970-979 (2015).

45. W.-Z. Zhu, Y. Xie, K. W. Moyes, J. D. Gold, B. Askari, M. A. Laflamme, Neuregulin/ErbB signaling regulates cardiac subtype specification in differentiating human embryonic stem cells. Circ. Res. 107, 776-786 (2010). 
46. D. L. Davis, A. V. Edwards, A. L. Juraszek, A. Phelps, A. Wessels, J. B. E. Burch, A GATA-6 gene heart-region-specific enhancer provides a novel means to mark and probe a discrete component of the mouse cardiac conduction system. Mech. Dev. 108, 105-119 (2001).

47. S. I. Protze, J. Liu, U. Nussinovitch, L. Ohana, P. H. Backx, L. Gepstein, G. M. Keller, Sinoatrial node cardiomyocytes from human pluripotent stem cells function as biological pacemaker. Nat. Biotechnol. 35, 56-68 (2017).

48. K. Maass, A. Shekhar, J. Lu, G. Kang, F. See, E. E. Kim, C. Delgado, S. Shen, L. Cohen, G. I. Fishman, Isolation and characterization of embryonic stem cell-derived cardiac Purkinje cells. Stem Cells 33, 1102-1112 (2015).

49. S.-Y. Tsai, K. Maass, J. Lu, G. I. Fishman, S. Chen, T. Evans, Efficient generation of cardiac purkinje cells from ESCs by activating cAMP signaling. Stem Cell Reports 4, 1089-1102 (2015).

50. H. M. Haqqani, J. M. Kalman, Aging and Sinoatrial node dysfunction. Circulation 115 , 1178-1179 (2007).

51. J. B. Anderson, D. W. Benson, Genetics of sick sinus syndrome. Card. Electrophysiol. Clin. 2, 499-507 (2010).

52. M. S. Olesen, M. W. Nielsen, S. H. Oslash, J. H. Svendsen, Atrial fibrillation: The role of common and rare genetic variants. Eur. J. Hum. Genet. 22, 297-306 (2013).

53. Z. Laksman, M. Wauchop, E. Lin, S. Protze, J. Lee, W. Yang, F. Izaddoustdar, S. Shafaattalab, L. Gepstein, G. F. Tibbits, G. Keller, P. H. Backx, Modeling atrial fibrillation using human embryonic stem cell-derived atrial tissue. Sci. Rep. 7, 5628 (2017).

54. A. Moretti, M. Bellin, A. Welling, C. B. Jung, J. T. Lam, L. Bott-Flügel, T. Dorn, A. Goedel, C. Höhnke, F. Hofmann, M. Seyfarth, D. Sinnecker, A. Schömig, K.-L. Laugwitz, Patient-specific induced pluripotent stem-cell models for long-QT syndrome. N. Engl. J. Med. 363, 1397-1409 (2010)

55. R. P. Davis, S. Casini, C. W. van den Berg, M. Hoekstra, C. A. Remme, C. Dambrot, D. Salvatori, D. W.-V. Oostwaard, A. A. M. Wilde, C. R. Bezzina, A. O. Verkerk, C. Freund, C. L. Mummery, Cardiomyocytes derived from pluripotent stem cells recapitulate electrophysiological characteristics of an overlap syndrome of cardiac sodium channel disease. Circulation 125, 3079-3091 (2012).

56. I. Itzhaki, L. Maizels, I. Huber, L. Zwi-Dantsis, O. Caspi, A. Winterstern, O. Feldman, A. Gepstein, G. Arbel, H. Hammerman, M. Boulos, L. Gepstein, Modelling the long QT syndrome with induced pluripotent stem cells. Nature 471, 225-229 (2011).

57. M. Yazawa, B. Hsueh, X. Jia, A. M. Pasca, J. A. Bernstein, J. Hallmayer, R. E. Dolmetsch, Using induced pluripotent stem cells to investigate cardiac phenotypes in Timothy syndrome. Nature 471, 230-234 (2011).

58. I. Itzhaki, L. Maizels, I. Huber, A. Gepstein, G. Arbel, O. Caspi, L. Miller, B. Belhassen, E. Nof, M. Glikson, L. Gepstein, Modeling of catecholaminergic polymorphic ventricular tachycardia with patient-specific human-induced pluripotent stem cells. J. Am. Coll. Cardiol. 60, 990-1000 (2012)

59. C. B. Jung, A. Moretti, M. Mederos y Schnitzler, L. lop, U. Storch, M. Bellin, T. Dorn, S. Ruppenthal, S. Pfeiffer, A. Goedel, R. J. Dirschinger, M. Seyfarth, J. T. Lam, D. Sinnecker, T. Gudermann, P. Lipp, K.-L. Laugwitz, Dantrolene rescues arrhythmogenic RYR2 defect in a patient-specific stem cell model of catecholaminergic polymorphic ventricular tachycardia. EMBO Mol. Med. 4, 180-191 (2012).

60. C. Kim, J. Wong, J. Wen, S. Wang, C. Wang, S. Spiering, N. G. Kan, S. Forcales, P. L. Puri, T. C. Leone, J. E. Marine, H. Calkins, D. P. Kelly, D. P. Judge, H.-S. V. Chen, Studying arrhythmogenic right ventricular dysplasia with patient-specific iPSCs. Nature 494, 105-110 (2013).

61. X. Carvajal-Vergara, A. Sevilla, S. L. D'Souza, Y.-S. Ang, C. Schaniel, D.-F. Lee, L. Yang, A. D. Kaplan, E. D. Adler, R. Rozov, Y. Ge, N. Cohen, L. J. Edelmann, B. Chang, A. Waghray, J. Su, S. Pardo, K. D. Lichtenbelt, M. Tartaglia, B. D. Gelb, I. R. Lemischka, Patient-specific induced pluripotent stem-cell-derived models of LEOPARD syndrome. Nature $\mathbf{4 6 5}$, 808-812 (2010).

62. N. Sun, M. Yazawa, J. Liu, L. Han, V. Sanchez-Freire, O. J. Abilez, E. G. Navarrete, S. Hu, L. Wang, A. Lee, A. Pavlovic, S. Lin, R. Chen, R. J. Hajjar, M. P. Snyder, R. E. Dolmetsch, M. J. Butte, E. A. Ashley, M. T. Longaker, R. C. Robbins, J. C. Wu, Patient-specific induced pluripotent stem cells as a model for familial dilated cardiomyopathy. Sci. Transl. Med. 4, 130ra47 (2012)

63. M. J. Birket, M. C. Ribeiro, G. Kosmidis, D. Ward, A. R. Leitoguinho, V. van de Pol, C. Dambrot, H. D. Devalla, R. P. Davis, P. G. Mastroberardino, D. E. Atsma, R. Passier, C. L. Mummery, Contractile defect caused by mutation in MYBPC3 revealed under conditions optimized for human PSC-cardiomyocyte function. Cell Rep. 13, 733-745 (2015).

64. F. Lan, A. S. Lee, P. Liang, V. Sanchez-Freire, P. K. Nguyen, L. Wang, L. Han, M. Yen, Y. Wang, N. Sun, O. J. Abilez, S. Hu, A. D. Ebert, E. G. Navarrete, C. S. Simmons, M. Wheeler, B. Pruitt, R. Lewis, Y. Yamaguchi, E. A. Ashley, D. M. Bers, R. C. Robbins, M. T. Longaker, J. C. Wu, Abnormal calcium handling properties underlie familial hypertrophic cardiomyopathy pathology in patient-specific induced pluripotent stem cells. Cell Stem Cell 12, 101-113 (2013).
65. Y. Jiang, S. Habibollah, K. Tilgner, J. Collin, T. Barta, J. Y. Al-Aama, L. Tesarov, R. Hussain, A. W. Trafford, G. Kirkwood, E. Sernagor, C. G. Eleftheriou, S. Przyborski, M. Stojković, M. Lako, B. Keavney, L. Armstrong, An induced pluripotent stem cell model of hypoplastic left heart syndrome (HLHS) reveals multiple expression and functional differences in HLHS-derived cardiac myocytes. Stem Cells Transl. Med. 3, 416-423 (2014).

66. A. Zimmermann, P. Diem, H. Cottier, Congenital "histiocytoid" cardiomyopathy: Evidence suggesting a developmental disorder of the Purkinje cell system of the heart. Virchows Arch. A Pathol. Anat. Histol. 396, 187-195 (1982).

67. S. Niwano, J. Kojima, H. Fukaya, D. Sato, M. Moriguchi, H. Niwano, Y. Masaki, T. Izumi, Arrhythmogenic difference between the left and right atria during rapid atrial activation in a canine model of atrial fibrillation. Circ. J. 71, 1629-1635 (2007).

68. M. Haïssaguerre, P. Jaïs, D. C. Shah, A. Takahashi, M. Hocini, G. Quiniou, S. Garrigue, A. Le Mouroux, P. Le Métayer, J. Clémenty, Spontaneous initiation of atrial fibrillation by ectopic beats originating in the pulmonary veins. N. Engl. J. Med. 339, 659-666 (1998).

69. A. Chinchilla, H. Daimi, E. Lozano-Velasco, J. N. Dominguez, R. Caballero, E. Delpón, J. Tamargo, J. Cinca, L. Hove-Madsen, A. E. Aranega, D. Franco, PITX2 insufficiency leads to atrial electrical and structural remodeling linked to arrhythmogenesis. Circ. Cardiovasc. Genet. 4, 269-279 (2011).

70. G.-Y. Wang, D. T. McCloskey, S. Turcato, P. M. Swigart, P. C. Simpson, A. J. Baker, Contrasting inotropic responses to $\alpha_{1}$-adrenergic receptor stimulation in left versus right ventricular myocardium. Am. J. Physiol. Heart Circ. Physiol. 291, H2013-H2017 (2006).

71. M. Strniskova, T. Ravingerová, J. Neckar, F. Kolár, S. Pastoreková, M. Barancík, Changes in the expression and/or activation of regulatory proteins in rat hearts adapted to chronic hypoxia. Gen. Physiol. Biophys. 25, 25-41 (2006).

72. R. Josowitz, J. Lu, C. Falce, S. L. D'Souza, M. Wu, N. Cohen, N. C. Dubois, Y. Zhao, E. A. Sobie, G. I. Fishman, B. D. Gelb, H. S. Bernstein, Identification and purification of human induced pluripotent stem cell-derived atrial-like cardiomyocytes based on sarcolipin expression. PLOS ONE 9, e101316 (2014).

73. V. Schwach, A. O. Verkerk, M. Mol, J. J. Monshouwer-Kloots, H. D. Devalla, V. V. Orlova, K. Anastassiadis, C. L. Mummery, R. P. Davis, R. Passier, A COUP-TFIl human embryonic stem cell reporter line to identify and select atrial cardiomyocytes. Stem Cell Reports 1765-1779 (2017).

74. I. Huber, I. Itzhaki, O. Caspi, G. Arbel, M. Tzukerman, A. Gepstein, M. Habib, L. Yankelson, I. Kehat, L. Gepstein, Identification and selection of cardiomyocytes during human embryonic stem cell differentiation. FASEB J. 21, 2551-2563 (2007).

75. E. Brauchle, A. Knopf, H. Bauer, N. Shen, S. Linder, M. G. Monaghan, K. Ellwanger, S. L. Layland, S. Y. Brucker, A. Nsair, K. Schenke-Layland, Non-invasive chamber-specific identification of cardiomyocytes in differentiating pluripotent stem cells. Stem Cell Reports 6, 188-199 (2016).

76. S. M. Chuva de Sousa Lopes, R. J. Hassink, A. Feijen, M. A. van Rooijen, P. A. Doevendans, L. Tertoolen, A. Brutel de la Rivière, C. L. Mummery, Patterning the heart, a template for human cardiomyocyte development. Dev. Dyn. 235, 1994-2002 (2006).

77. A. Scavone, D. Capilupo, N. Mazzocchi, A. Crespi, S. Zoia, G. Campostrini, A. Bucchi, R. Milanesi, M. Baruscotti, S. Benedetti, S. Antonini, G. Messina, D. DiFrancesco, A. Barbuti, Embryonic stem cell-derived $C D 166^{+}$precursors develop into fully functional sinoatrial-like cells. Circ. Res. 113, 389-398 (2013).

78. W. Rust, T. Balakrishnan, R. Zweigerdt, Cardiomyocyte enrichment from human embryonic stem cell cultures by selection of ALCAM surface expression. Regen. Med. 4, 225-237 (2009).

79. M. Gherghiceanu, L. Barad, A. Novak, I. Reiter, J. Itskovitz-Eldor, O. Binah, L. M. Popescu, Cardiomyocytes derived from human embryonic and induced pluripotent stem cells: Comparative ultrastructure. J. Cell. Mol. Med. 15, 2539-2551 (2011).

80. C. L. Mummery, J. Zhang, E. S. Ng, D. A. Elliott, A. G. Elefanty, T. J. Kamp, Differentiation of human embryonic stem cells and induced pluripotent stem cells to cardiomyocytes: A methods overview. Circ. Res. 111, 344-358 (2012).

81. M. C. Ribeiro, L. G. Tertoolen, J. A. Guadix, M. Bellin, G. Kosmidis, C. D'Aniello, J. Monshouwer-Kloots, M.-J. Goumans, Y.-L. Wang, A. W. Feinberg, C. L. Mummery, R. Passier, Functional maturation of human pluripotent stem cell derived cardiomyocytes in vitro - Correlation between contraction force and electrophysiology. Biomaterials $\mathbf{5 1}$ 138-150 (2015).

82. G. D. Lopaschuk, J. R. Ussher, C. D. L. Folmes, J. S. Jaswal, W. C. Stanley, Myocardial fatty acid metabolism in health and disease. Physiol. Rev. 90, 207-258 (2010).

83. P. Rana, B. Anson, S. Engle, Y. Will, Characterization of human-induced pluripotent stem cell-derived cardiomyocytes: Bioenergetics and utilization in safety screening. Toxicol. Sci. 130, 117-131 (2012).

84. X. Yang, M. Rodriguez, L. Pabon, K. A. Fischer, H. Reinecke, M. Regnier, N. J. Sniadecki, H. Ruohola-Baker, C. E. Murry, Tri-iodo-L-thyronine promotes the maturation of human cardiomyocytes-derived from induced pluripotent stem cells. J. Mol. Cell. Cardiol. 72, 296-304 (2014).

85. Y. Tian, E. E. Morrisey, Importance of myocyte-nonmyocyte interactions in cardiac development and disease. Circ. Res. 110, 1023-1034 (2012). 
86. D. S. Lee, J.-H. Chen, D. J. Lundy, C.-H. Liu, S.-M. Hwang, L. Pabon, R.-C. Shieh, C.-C. Chen, S.-N. Wu, Y.-T. Yan, S.-T. Lee, P.-M. Chiang, S. Chien, C. E. Murry, P. C. H. Hsieh, Defined microRNAs induce aspects of maturation in mouse and human embryonic-stem-cellderived cardiomyocytes. Cell Rep. 12, 1960-1967 (2015).

87. K. T. Kuppusamy, D. C. Jones, H. Sperber, A. Madan, K. A. Fischer, M. L. Rodriguez, L. Pabon, W.-Z. Zhu, N. L. Tulloch, X. Yang, N. J. Sniadecki, M. A. Laflamme, W. L. Ruzzo, C. E. Murry, H. Ruohola-Baker, Let-7 family of microRNA is required for maturation and adult-like metabolism in stem cell-derived cardiomyocytes. Proc. Natl. Acad. Sci. U.S.A. 112, E2785-E2794 (2015).

88. J.-L. Ruan, N. L. Tulloch, M. Saiget, S. L. Paige, M. V. Razumova, M. Regnier, K. C. Tung, G. Keller, L. Pabon, H. Reinecke, C. E. Murry, Mechanical stress promotes maturation of human myocardium from pluripotent stem cell-derived progenitors. Stem Cells 33, 2148-2157 (2015).

89. G. Eng, B. W. Lee, L. Protas, M. Gagliardi, K. Brown, R. S. Kass, G. Keller, R. B. Robinson, G. Vunjak-Novakovic, Autonomous beating rate adaptation in human stem cell-derived cardiomyocytes. Nat. Commun. 7, 10312 (2016).

90. S. S. Nunes, J. W. Miklas, J. Liu, R. Aschar-Sobbi, Y. Xiao, B. Zhang, J. Jiang, S. Massé, M. Gagliardi, A. Hsieh, N. Thavandiran, M. A. Laflamme, K. Nanthakumar, G. J. Gross, P. H. Backx, G. Keller, M. Radisic, Biowire: A platform for maturation of human pluripotent stem cell-derived cardiomyocytes. Nat. Methods 10, 781-787 (2013).

91. A. R. Pinto, A. Ilinykh, M. J. Ivey, J. T. Kuwabara, M. D'Antoni, R. J. Debuque, A. Chandran, L. Wang, K. Arora, N. Rosenthal, M. D. Talliquist, Revisiting cardiac cellular composition. Circ. Res. 118, 400-409 (2016).

92. R. G. Gourdie, Y. Wei, D. Kim, S. C. Klatt, T. Mikawa, Endothelin-induced conversion of embryonic heart muscle cells into impulse-conducting Purkinje fibers. Proc. Natl. Acad. Sci. U.S.A. 95, 6815-6818 (1998).

93. M. Masters, P. Riley, The epicardium signals the way towards heart regeneration. Stem Cell Res. 13, 683-692 (2014).

94. E. M. Zeisberg, R. Kalluri, Origins of cardiac fibroblasts. Circ. Res. 107, 1304-1312 (2010).

95. M. leda, T. Tsuchihashi, K. N. Ivey, R. S. Ross, T.-T. Hong, R. M. Shaw, D. Srivastava, Cardiac fibroblasts regulate myocardial proliferation through $\beta 1$ integrin signaling. Dev. Cell 16, 233-244 (2009).

96. V. V. Orlova, F. E. van de Hill, S. Petrus-Reurer, Y. Drabsch, P. Ten Dijke, C. L. Mummery, Generation, expansion and functional analysis of endothelial cells and pericytes derived from human pluripotent stem cells. Nat. Protoc. 9, 1514-1531 (2014).

97. C. Patsch, L. Challet-Meylan, E. C. Thoma, E. Urich, T. Heckel, J. F. O'Sullivan, S. J. Grainger, F. G. Kapp, L. Sun, K. Christensen, Y. Xia, M. H. C. Florido, W. He, W. Pan, M. Prummer, C. R. Warren, R. Jakob-Roetne, U. Certa, R. Jagasia, P.-O. Freskgård, I. Adatto, D. Kling, P. Huang, L. I. Zon, E. L. Chaikof, R. E. Gerszten, M. Graf, R. lacone, C. A. Cowan, Generation of vascular endothelial and smooth muscle cells from human pluripotent stem cells. Nat. Cell Biol. 17, 994-1003 (2015).

98. A. D. Witty, A. Mihic, R. Y. Tam, S. A. Fisher, A. Mikryukov, M. S. Shoichet, R.-K. Li, S. J. Kattman, G. Keller, Generation of the epicardial lineage from human pluripotent stem cells. Nat. Biotechnol. 32, 1026-1035 (2014).

99. D. Iyer, L. Gambardella, W. G. Bernard, F. Serrano, V. L. Mascetti, R. A. Pederson, A. Talasila, S. Sinha, Robust derivation of epicardium and its differentiated smooth muscle cell progeny from human pluripotent stem cells. Development 142, 1528-1541 (2015).

100. J. A. Guadix, V. V. Orlova, E. Giacomelli, M. Bellin, M. C. Ribeiro C. L. Mummery, J. M. Pérez Pomares, R. Passier, Human pluripotent stem cell differentiation into functional epicardial progenitor cells. Stem Cell Reports 9, 1754-1764 (2017).

101. W. H. Zimmermann, K. Schneiderbanger, P. Schubert, M. Didié, F. Münzel, J. F. Heubach, S. Kostin, W. L. Neuhuber, T. Eschenhagen, Tissue engineering of a differentiated cardiac muscle construct. Circ. Res. 90, 223-230 (2002).

102. W.-H. Zimmermann, I. Melnychenko, G. Wasmeier, M. Didié, H. Naito, U. Nixdorff, A. Hess, L. Budinsky, K. Brune, B. Michaelis, S. Dhein, A. Schwoerer, H. Ehmke, T. Eschenhagen, Engineered heart tissue grafts improve systolic and diastolic function in infarcted rat hearts. Nat. Med. 12, 452-458 (2006).

103. M. Radisic, H. Park, F. Chen, J. E. Salazar-Lazzaro, Y. Wang, R. Dennis, R. Langer, L. E. Freed, G. Vunjak-Novakovic, Biomimetic approach to cardiac tissue engineering: Oxygen carriers and channeled scaffolds. Tissue Eng. 12, 2077-2091 (2006).

104. O. Caspi, A. Lesman, Y. Basevitch, A. Gepstein, G. Arbel, I. H. M. Habib, L. Gepstein, S. Levenberg, Tissue engineering of vascularized cardiac muscle from human embryonic stem cells. Circ. Res. 100, 263-272 (2007).

105. K. R. Stevens, K. L. Kreutziger, S. K. Dupras, F. S. Korte, M. Regnier, V. Muskheli, M. B. Nourse, K. Bendixen, H. Reinecke, C. E. Murry, Physiological function and transplantation of scaffold-free and vascularized human cardiac muscle tissue. Proc. Natl. Acad. Sci. U.S.A. 106, 16568-16573 (2009).

106. N. L. Tulloch, V. Muskheli, M. V. Razumova, F. S. Korte, M. Regnier, K. D. Hauch, L. Pabon, $\mathrm{H}$. Reinecke, C. E. Murry, Growth of engineered human myocardium with mechanical loading and vascular coculture. Circ. Res. 109, 47-59 (2011).
107. S. Schaaf, A. Shibamiya, M. Mewe, A. Eder, A. Stöhr, M. N. Hirt, T. Rau, W.-H. Zimmermann, L. Conradi, T. Eschenhagen, A. Hansen, Human engineered heart tissue as a versatile tool in basic research and preclinical toxicology. PLOS ONE 6, e26397 (2011).

108. M. Tiburcy, J. E. Hudson, P. Balfanz, S. Schlick, T. Meyer, M. L. Chang Liao, E. Levent, F. Raad, S. Zeidler, E. Wingender, J. Riegler, M. Wang, J. D. Gold, I. Kehat, E. Wettwer, U. Ravens, P. Dierickx, L. W. van Laake, M. J. Goumans, S. Khadjeh, K. Toischer, G. Hasenfuss, L. A. Couture, A. Unger, W. A. Linke, T. Araki, B. Neel, G. Keller, L. Gepstein, J. C. Wu, W.-H. Zimmermann, Defined engineered human myocardium with advanced maturation for applications in heart failure modeling and repair. Circulation 135, 1832-1847 (2017).

109. M. N. Hirt, J. Boeddinghaus, A. Mitchell, S. Schaaf, C. Börnchen, C. Müller, H. Schulz, N. Hubner, J. Stenzig, A. Stoehr, C. Neuber, A. Eder, P. K. Luther, A. Hansen, T. Eschenhagen, Functional improvement and maturation of rat and human engineered heart tissue by chronic electrical stimulation. J. Mol. Cell. Cardiol. 74, 151-161 (2014).

110. H. C. Ott, T. S. Matthiesen, S.-K. Goh, L. D. Black, S. M. Kren, T. I. Netoff, D. A. Taylor, Perfusion-decellularized matrix: Using nature's platform to engineer a bioartificial heart. Nat. Med. 14, 213-221 (2008).

111. J. P. Guyette, J. Charest, R. W. Mills, B. Jank, P. T. Moser, S. E. Gilpin, J. R. Gershlak, T. Okamoto, G. Gonzalez, D. J. Milan, G. R. Gaudette, H. C. Ott, Bioengineering human myocardium on native extracellular matrix. Circ. Res. 118, 56-72 (2016).

112. T.-Y. Lu, B. Lin, J. Kim, M. Sullivan, K. Tobita, G. Salama, L. Yang, Repopulation of decellularized mouse heart with human induced pluripotent stem cell-derived cardiovascular progenitor cells. Nat. Commun. 4, 2307 (2013).

113. C. Willyard, The boom in mini stomachs, brains, breasts, kidneys and more. Nature $\mathbf{5 2 3}$, 520-522 (2015).

114. S. V. Murphy, A. Atala, 3D bioprinting of tissues and organs. Nat. Biotechnol. 32, 773-785 (2014).

115. J. Hinton, Q. Jallerat, R. N. Palchesko, J. H. Park, M. S. Grodzicki, H.-J. Shue, M. H. Ramadan, A. R. Hudson, A. W. Feinberg, Three-dimensional printing of complex biological structures by freeform reversible embedding of suspended hydrogels. Sci. Adv. 1, e1500758 (2015).

116. A. Faulkner-Jones, C. Fyfe, D.-J. Cornelissen, J. Gardner, J. King, A. Courtney, W. Shu, Bioprinting of human pluripotent stem cells and their directed differentiation into hepatocyte-like cells for the generation of mini-livers in 3D. Biofabrication 7, 044102 (2015).

117. H.-W. Kang, S. J. Lee, I. K. Ko, C. Kengla, J. J. Yoo, A. Atala, A 3D bioprinting system to produce human-scale tissue constructs with structural integrity. Nat. Biotechnol. 34, 312-319 (2016).

118. R. Passier, V. Orlova, C. L. Mummery, Complex tissue and disease modeling using hiPSCs. Cell Stem Cell 18, 309-321 (2016).

119. O. Caspi, I. Huber, I. Kehat, M. Habib, G. Arbel, A. Gepstein, L. Yankelson, D. Aronson, R. Beyar, L. Gepstein, Transplantation of human embryonic stem cell-derived cardiomyocytes improves myocardial performance in infarcted rat hearts. J. Am. Coll. Cardiol. 50, 1884-1893 (2007).

120. L. W. van Laake, R. Passier, J. Monshouwer-Kloots, A. J. Verkleij, D. J. Lips, C. Freund, K. den Ouden, D. Ward-van Oostwaard, J. Korving, L. G. Tertoolen, C. J. van Echteld, P. A. Doevendans, C. L. Mummery, Human embryonic stem cell-derived cardiomyocytes survive and mature in the mouse heart and transiently improve function after myocardial infarction. Stem Cell Res. 1, 9-24 (2007).

121. M. A. Laflamme, K. Y. Chen, A. V. Naumova, V. Muskheli, J. A. Fugate, S. K. Dupras, H. Reinecke, C. Xu, M. Hassanipour, S. Police, C. O'Sullivan, L. Collins, Y. Chen, E. Minami, E. A. Gill, S. Ueno, C. Yuan, J. Gold, C. E. Murry, Cardiomyocytes derived from human embryonic stem cells in pro-survival factors enhance function of infarcted rat hearts. Nat. Biotechnol. 25, 1015-1024 (2007).

122. J. Riegler, M. Tiburcy, A. Ebert, E. Tzatzalos, U. Raaz, O. J. Abilez, Q. Shen, N. G. Kooreman, E. Neofytou, V. Chen, M. Wang, T. Meyer, P. S. Tsao, A. J. Connolly, L. A. Couture, J. D. Gold, W. H. Zimmermann, J. C. Wu, Human engineered heart muscles engraft and survive long-term in a rodent myocardial infarction model. Circ. Res. 117, 720-730 (2015).

123. J. J. H. Chong, X. Yang, C. W. Don, E. Minami, Y.-W. Liu, J. J. Weyers, W. M. Mahoney, B. Van Biber, S. M. Cook, N. J. Palpant, J. A. Gantz, J. A. Fugate, V. Muskheli, G. M. Gough, K. W. Vogel, C. A. Astley, C. E. Hotchkiss, A. Baldessari, L. Pabon, H. Reinecke, E. A. Gill, V. Nelson, H.-P. Kiem, M. A. Laflamme, C. E. Murry, Human embryonic-stem-cell-derived cardiomyocytes regenerate non-human primate hearts. Nature 510, 273-277 (2014).

124. P. Menasché, V. Vanneaux, J. R. Fabreguettes, A. Bel, L. Tosca, S. Garcia, V. Bellamy, Y. Farouz, J. Pouly, O. Damour, M.-C. Périer, M. Desnos, A. Hagège, O. Agbulut, P. Bruneval, G. Tachdjian, J.-H. Trouvin, J. Larghero, Towards a clinical use of human embryonic stem cell-derived cardiac progenitors: A translational experience. Eur. Heart J. 36, 743-750 (2015).

125. P. Menasché, V. Vanneaux, A. Hagège, A. Bel, B. Cholley, I. Cacciapuoti, A. Parouchev, N. Benhamouda, G. Tachdjian, L. Tosca, J.-H. Trouvin, J.-R. Fabreguettes, V. Bellamy, R. Guillemain, C. Suberbielle Boissel, E. Tartour, M. Desnos, J. Larghero, Human 
embruonic stem cell-derived cardiac progenitors for severe heart failure: First clinical case report. Eur. Heart J. 36, 2011-2017 (2015).

126. S. Fernandes, J. J. H. Chong, S. L. Paige, M. Iwata, B. Torok-Storb, G. Keller, H. Reinecke, C. E. Murry, Comparison of human embryonic stem cell-derived cardiomyocytes, cardiovascular progenitors and bone marrow mononuclear cells for cardiac repair. Stem Cell Reports 5, 753-762 (2015).

127. L. Yang, M. H. Soonpa, E. D. Adler, T. K. Roepke, S. J. Kattman, M. Kennedy, E. Henckaerts, K. Bonham, G. W. Abbott, R. M. Linden, L. J. Field, G. M. Keller, Human cardiovascular progenitor cells develop from a $\mathrm{KDR}^{+}$embryonic stem cell-derived population. Nature 453, 524-528 (2008).

128. T. L. Mirensky, C. K. Breuer, The development of tissue-engineered grafts for reconstructive cardiothoracic surgical applications. Pediatr. Res. 63, 559-568 (2008).
Acknowledgments: We thank $\mathrm{M}$. Jongbloed for the critical reading of this article and B. Blankevoort and K. Gkatzis for the illustration design. Funding: R.P. is supported by ZonMWMKMD-40-42600-98-036, ERA-CVD 2016T092, and Eurostars Cardiopredict. H.D.D. is supported by Eurostars Cardiopredict. Competing interests: R.P. is a cofounder of Pluriomics (Ncardia).

Submitted 21 September 2015

Resubmitted 15 July 2016

Accepted 20 June 2017

Published 4 April 2018

10.1126/scitransImed.aah5457

Citation: H. D. Devalla, R. Passier, Cardiac differentiation of pluripotent stem cells and implications for modeling the heart in health and disease. Sci. Transl. Med. 10, eaah5457 (2018). 


\section{Abstract}

One-sentence summary: Differentiation of human pluripotent stem cells into cardiomyocytes and other cardiac cells enables modeling of heart function and elucidation of disease pathogenesis. 